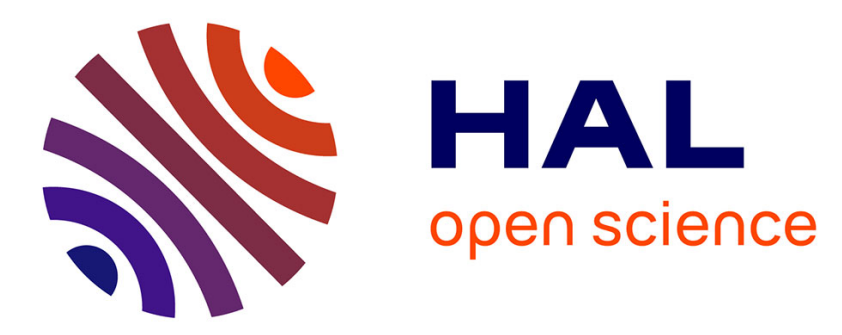

\title{
Osmium isotope evidence for rapid melt migration towards the Moho in the Oman ophiolite
}

Delphine Klaessens, Laurie Reisberg, David Jousselin, Marguerite Godard, Claire Aupart

\section{- To cite this version:}

Delphine Klaessens, Laurie Reisberg, David Jousselin, Marguerite Godard, Claire Aupart. Osmium isotope evidence for rapid melt migration towards the Moho in the Oman ophiolite. Earth and Planetary Science Letters, 2021, 572, pp.117111. 10.1016/j.epsl.2021.117111 . hal-03328806

\section{HAL Id: hal-03328806 \\ https://hal.univ-lorraine.fr/hal-03328806}

Submitted on 30 Aug 2021

HAL is a multi-disciplinary open access archive for the deposit and dissemination of scientific research documents, whether they are published or not. The documents may come from teaching and research institutions in France or abroad, or from public or private research centers.
L'archive ouverte pluridisciplinaire HAL, est destinée au dépôt et à la diffusion de documents scientifiques de niveau recherche, publiés ou non, émanant des établissements d'enseignement et de recherche français ou étrangers, des laboratoires publics ou privés.

\section{(ㅇ)(1) $\$$}

Distributed under a Creative Commons Attribution - NonCommercial - NoDerivatives| 4.0 
1 Osmium isotope evidence for rapid melt migration towards the Moho in the

2 Oman ophiolite

3 Delphine KLAESSENS ${ }^{1 *}$, Laurie REISBERG ${ }^{1}$, David JOUSSELIN ${ }^{1}$, Marguerite GODARD $^{2}$, Claire AUPART ${ }^{3}$

$4{ }^{1}$ Centre de Recherches Pétrographiques et Géochimiques, UMR 7358 CNRS - Université de Lorraine, 15

5 rue Notre Dame des Pauvres, F-54501 Vandœuvre-lès-Nancy, France

$6 \quad{ }^{2}$ Géosciences Montpellier, CNRS, Université de Montpellier, Montpellier, France

$7 \quad{ }^{3}$ Physics of Geological Processes (PGP), The Njord Centre, Dept. of Geosciences, University of Oslo, PO

8 Box 1048, N-0316, Oslo, Norway

9 (*correspondence: $\underline{\text { delphine.klaessens@univ-lorraine.fr) }}$ 
The oceanic crust, covering two-thirds of the Earth's surface, is formed along mid-oceanic ridges by crystallization at shallow levels of melts formed at depth by partial melting of mantle peridotite. Yet, the process of melt transport to the ridge axis remains poorly understood. Ophiolites, which provide a window into the uppermost mantle, contain dunite bodies often interpreted as relics of melt flow conduits, formed by pyroxene dissolution during melt-peridotite interaction. Here, we present structural and geochemical data on peridotites from the southeastern Oman ophiolite where three types of dunite, corresponding to the Moho transition zone (MTZ), the main and basal mantle sections, are identified. We focus on osmium isotopes, which are particularly well-adapted to tracing melt flow through peridotites. Osmium isotope signatures from host harzburgites accord with abyssal peridotite values and do not vary systematically with setting. In contrast, dunite Os compositions depend on structural context. Basal dunites display compositions similar to harzburgite values, while MTZ dunites have highly radiogenic compositions similar to those of the overlying crust, requiring extensive interaction with melts more radiogenic than MORB. Modeling shows that melts percolating through and equilibrating with dunite channels would acquire unradiogenic compositions, inconsistent with the observed Os signatures of MTZ dunites and lower crust. Thus, our findings require melt transport without equilibration with dunite or harzburgite, arguing for rapid or at least chemically isolated melt migration from the mantle source to the Moho.

\section{3 words}


Oman ophiolite, Mantle, Osmium isotopes, Melt migration, Dunite

\section{$\underline{\text { Highlights }}$}

1. Distinction of three types of dunite in the mantle section of SE Oman ophiolite

2. Strong correlation between dunite Os isotope composition and structural context

3. MTZ dunites interacted extensively with melts more radiogenic than MORB

4. High ${ }^{187} \mathrm{Os} /{ }^{188} \mathrm{Os}$ at odds with melt transport by percolation in dunite channels

5. Rapid/chemically isolated melt transport needed to maintain radiogenic signatures 
Melt migration processes beneath mid-oceanic ridges remain controversial, engendering a diversity of models based on structural (Nicolas, 1986), geochemical (Kelemen et al., 1995), petrological (Morgan and Liang, 2003) and numerical studies (Ahern and Turcotte, 1979; Stevenson, 1989). One strong

constraint is the existence of disequilibrium between shallow mantle peridotites and mid-ocean ridge basalts (MORBs) (O'Hara, 1965; Stolper, 1980), manifested notably by undersaturation of orthopyroxene (opx) in MORBs. Melt-peridotite interactions can result in pyroxene dissolution in the host peridotite (Kelemen, 1990; Lambart et al., 2009; Morgan and Liang, 2003), forming dunite if continued to completion. The origin of ophiolitic dunite bodies is commonly attributed to this process (Boudier and Nicolas, 1977, 1995; Büchl et al., 2002, 2004; O’Driscoll et al., 2012), which may generate dunite channels providing transport pathways for ascending melts (Kelemen et al., 1995). In such channels, melts are isolated from equilibration with the surrounding peridotite, but may equilibrate with the dunite.

The Oman ophiolite is well-suited for the study of melt migration beneath mid-oceanic ridges. This large (>20 $000 \mathrm{~km}^{2}$ ), well-exposed segment of oceanic lithosphere, formed $\sim 95 \mathrm{Ma}$ ago along a rapid spreading center (Boudier et al., 1997; Nicolas et al., 2000a; Rioux et al., 2012), provides a window into the uppermost mantle, which outcrops over $>50 \%$ of its surface. The Re-Os radiometric system, in which ${ }^{187}$ Re decays to ${ }^{187}$ Os ( $t_{1 / 2}=41.6 \mathrm{Ga}, \lambda=1.666 \times 10^{-11}$ ) (Smoliar et al., 1996), is a particularly useful tool for studying mantle melt transport. The contrasting behavior of these two elements during partial melting (rhenium is moderately incompatible while osmium is compatible) creates Earth reservoirs with strikingly different Re/Os ratios, producing over time contrasting Os isotope ratios. Recycled oceanic crust and sediments develop highly radiogenic Os compositions while mantle peridotites remain unradiogenic. When melt migrates through dunite, the isotopic and elemental compositions of incompatible elements (e.g. light rare earth elements) are rapidly overprinted in the dunite by equilibration with the magma, which has much higher concentrations of these elements. For Os, the mass balance is reversed, allowing gradual changes in Os isotope composition to be recorded in the dunite as melt progressively passes through. 
Here, we present structural observations and geochemical data on melt migration and dunite formation from peridotites from the southeastern Oman ophiolite. We focus on Os isotopes, tracers exceptionally well-adapted to studying melt-peridotite interactions. Implications of our results for melt transport mechanisms are modeled in light of the structural context of each sample.

\section{The Oman ophiolite}

\subsection{Internal structure}

As documented by early studies (e.g. Boudier and Coleman (1981); Lippard et al. (1986); Nicolas et al. (2000a)), the Oman ophiolite consists of a >15 kilometer thick dominantly harzburgitic mantle section, overlain by a complete mafic crust. Our study focuses on the mantle section. This domain was first detailed by Boudier and Coleman (1981), based on a cross-section in the Wadi Tayin massif. The uppermost few hundred meters beneath the crust correspond to the Moho Transition Zone (MTZ), a primarily dunitic layer of variable thickness. The MTZ has been extensively studied (e. g. Boudier and Nicolas (1995); Godard et al. (2000); Koga et al. (2001); Rospabé et al. (2018)) and is interpreted as a melt storage and reaction zone, where ascending melts stagnate beneath the crust-mantle interface (Moho). These melts dissolve orthopyroxene of the host harzburgite, producing both pure dunite and "melt-impregnated" dunite with interstitial plagioclase, pyroxene and occasional amphibole, as well as rare cumulate gabbro lenses $(<5 \%)$. In the lowermost $M T Z$, interfingering relationships between harzburgite and dunite with orthopyroxene relics suggest a melt-peridotite reactional origin for the dunite (Nicolas and Prinzhofer, 1983). Furthermore, the olivine $\mathrm{Mg \#}\left[=\mathrm{Mg} /\left(\mathrm{Mg}+\mathrm{Fe}_{\text {total }}\right)_{a t}\right]$ is similar in the MTZ and underlying harzburgite, whereas spinel $\mathrm{TiO}_{2}$ content in the $\mathrm{MTZ}$ is higher, indicating dunite arose from equilibration with $\mathrm{TiO}_{2}$-rich primary melts rather than crystal fractionation (Koga et al., 2001).

Beneath the MTZ, the primarily harzburgitic main mantle section (MMS) comprises most of the ophiolite volume. The exact distribution of dunite within the MMS is unclear and its estimated proportion varies between studies (e. g. <5\% for Boudier and Coleman (1981) and 5-15\% for Lippard et 
al. (1986)). Dunite occurs either as planar and irregular bodies with dimensions up to 20 meters (Bartholomew, 1983), crosscutting the mantle fabric, or more rarely, as thin concordant bands. Crosscutting gabbro and pyroxenite dikes are occasionally observed.

At the bottom of the mantle section near the basal thrust, a highly deformed, basal banded unit (BBU) is often observed. In this section, Boudier and Coleman (1981) report subequal proportions of harzburgite (or occasionally lherzolite) and concordant dunite bands, varying in thickness from 0.1 to several meters. Lippard et al. (1986) also note significantly increased dunite abundance near the base. These basal dunites have never been thoroughly nor systematically studied.

Braun and Kelemen (2002) determined a power law relationship between dunite width and cumulative abundance, which they used to support a model of melt transport to the ridge in coalescing dunite channels. The mid to large-sized dunites in their study were measured in the Muscat massif (Fig. 1). The proximity with the basal thrust and the exceptionally high dunite abundance (18$46 \%)$ of this small massif suggest that it is derived from the BBU.

\subsection{Geodynamic context}

The geodynamic context of the Oman ophiolite has long been controversial. The ophiolite presents several characteristics akin to those of fast spreading ridges (e. g. magma chamber shape, mantle structure, crustal continuity, structure and thickness variation...) (Boudier et al., 1997; Nicolas et al., 2000a). Moreover, basalts above the sheeted dike complex (V1, Geotimes unit) display MORB-like compositions (Ernewein et al., 1988; Godard et al., 2006). However, upper lavas (V2, Lasail unit, found in northern Oman) overlying hydrothermal deposits display island arc affinities (Alabaster et al., 1982; Ernewein et al., 1988), suggesting ophiolite formation in a supra-subduction setting. As these upper units clearly postdate most of the crustal accretion, and probably the recorded mantle flow, this origin has been disputed. However, reappraisal of the Geotimes unit (MacLeod et al., 2013) and dating of the metamorphic sole (Guilmette et al., 2018) strongly argue for accretion of the entire ophiolite from a hydrated mantle above a subducting slab. Nevertheless, the critical parameters controlling magmatic accretion at the ridge are spreading rate and presence or absence of a magma chamber, regardless of 
116 the broader tectonic context. Thus, the Oman ophiolite remains a well-suited laboratory for studying

117 melt migration in the mantle beneath accretion centers, as long as we focus on features

118 contemporaneous with the asthenospheric mantle flow.

119 Systematic petrostructural mapping (Nicolas et al. (2000a) and references therein) revealed the

120 deformation temperatures of the peridotite and their spatial variation. Coarse-grained granular and

121 porphyroclastic textures with well-recovered sub-structures are ascribed to asthenospheric

122 deformation at the spreading center. Finer-grained porphyroclastic textures with varying degrees of

123 recrystallization into neoblasts, mostly restricted to the borders of the massifs, reflect overprinting

124 low-temperature deformation, associated with ophiolite emplacement. Later faulting is limited. Thus,

125 the ophiolite can be seen as a fossilized piece of oceanic lithosphere, dissected by erosion and slightly

126 tilted following the dip of the Moho.

127 In the southeastern part of the ophiolite, the focus of our study, a NW-SE paleo-spreading center was

128 identified from dike orientations, which trend NW-SE in the center of the Sumail massif and

129 perpendicularly (NE-SW) to the north and south of this central zone (Fig. 1) (Boudier et al., 1997). The

130 position of this spreading center is inferred from the alignment of several harzburgitic mantle diapirs,

131 defined by steeply plunging lineations with radial horizontal lineations at their outskirts (Jousselin et

132 al., 1998). Solid-state flow lineations in the harzburgite and MTZ, and magmatic lineations in the

133 overlying crust are remarkably parallel, indicating that the mantle lineations formed before the gabbro

134 was frozen. These observations show that harzburgite diapirs, MTZ formation and ridge accretion

135 were contemporaneous, with diapirs being likely feeding centers for the overlying ridge segments. 


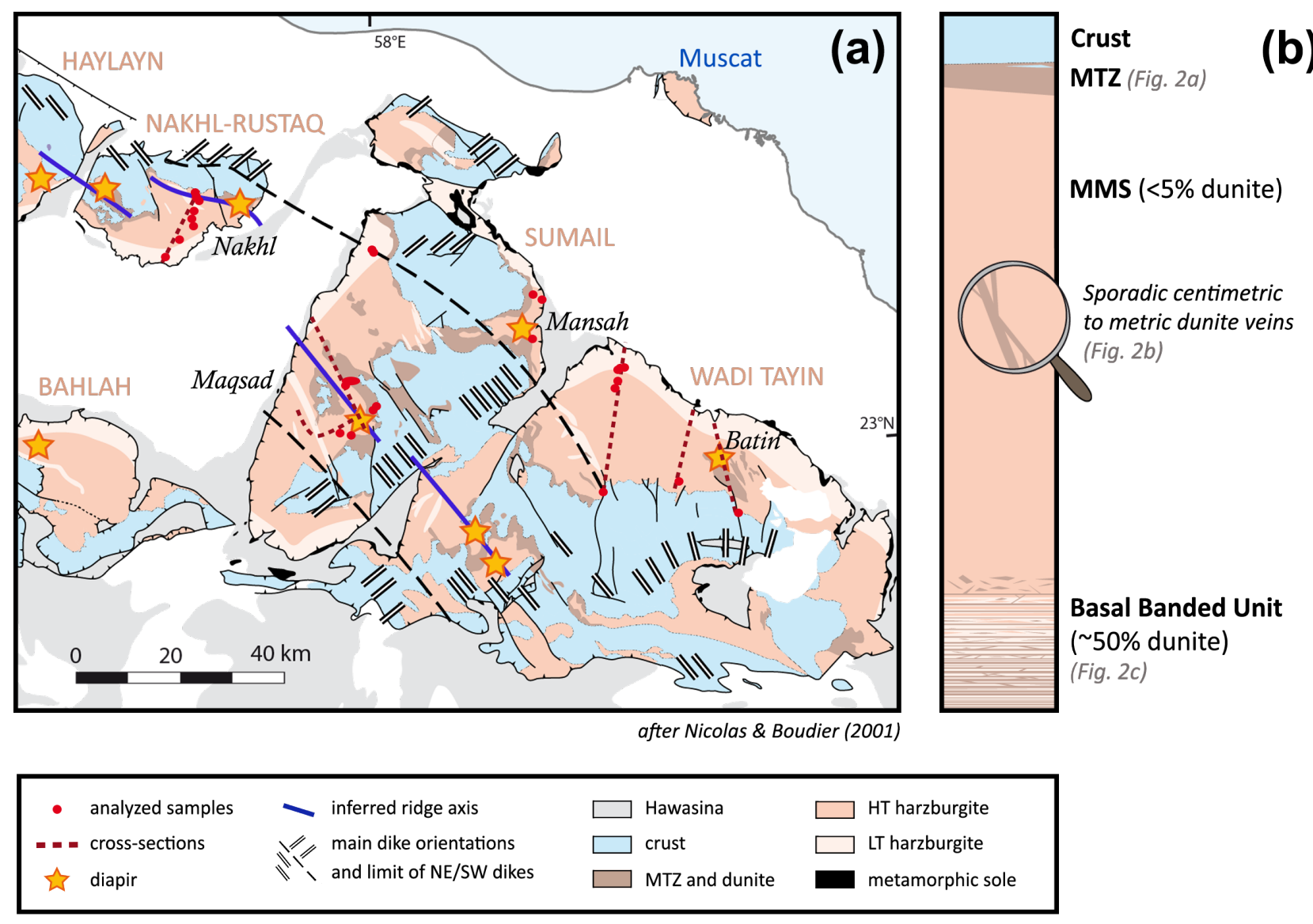

137 Fig. 1. Sample locations and structure of the southeastern part of the Oman ophiolite. (a) Simplified

138 geological map of the southeastern massifs (Nakhl-Rustaq, Sumail, Wadi Tayin and Haylayn) of the

139 Oman ophiolite (after Nicolas and Boudier (2001)) showing the sample locations (red dots) and the

140 spatial distribution of the crust, Moho Transition Zone (MTZ), mantle and metamorphic sole sections.

141 Most samples were collected along cross-sections (bold burgundy dotted lines) in on-axis and off-axis

142 settings. Hawasina sediments, inferred ridge axis (bold blue lines), mantle diapirs (stars), main dike

143 orientations (double black lines) and limits of NE-SW dikes (black dashed curves) are also shown. Batin

144 dunite (in dark brown) is visible in the Batin area in the eastern part of the Wadi Tayin massif, below

145 the diapir. (b) Schematic mantle cross-section based on field observations, showing the distribution of

146 the three types of dunite described in the text: Mantle transition zone (MTZ), sporadic centimetric to

147 metric veins in the main mantle section (MMS) and abundant bands in the basal banded unit (BBU).

148 (For interpretation of the colors in the figure(s), the reader is referred to the web version of this article.) 
150 To clarify dunite distribution, we made observations and collected samples along six cross-sections traversing the mantle section, in diapiric and non-diapiric areas in the Nakhl-Rustaq, Sumail (Maqsad diapir) and Wadi Tayin massifs (Fig. 1 and Fig. A.1). Complementary observations were made at sites near Muscat, at the base of the Haylayn massif and in the Batin area in the eastern part of Wadi Tayin.

Our observations distinguish three types of dunite, each associated with a specific part of the mantle section (Fig. 1-2; dunite thicknesses in Table A.1):

(1) Moho Transition Zone (MTZ) (Fig. 2a): As noted by previous studies (Boudier and Nicolas, 1995; Koga et al., 2001; Rospabé et al., 2018), the MTZ is composed of pure and plagioclase/clinopyroxeneimpregnated dunites, and reaches thicknesses of 50-500 meters above harzburgite diapirs, and usually $<30$ meters far from diapirs. Dunitic lenses several meters wide, interlayered with harzburgite, are

160 sometimes found in the hundred meters underlying the MTZ. The MTZ volume is so large that it can 161 be represented on maps including several massifs (scales of $1 / 1000000$ to 1/500 000) (Fig. 1).

162 (2) Harzburgitic main mantle section (MMS): Discordant gabbroic and pyroxenitic dikes rimmed by 163 dunitic reaction zones crosscut sporadically the MMS harzburgite (Fig. 2b left), as described by 164 Boudier and Coleman (1981). In some cases, all of the melt was extracted from the dike, leaving only 165 the dunitic reaction zones, several centimeters to 5 meters wide, crosscutting the mantle fabric 166 (henceforth such features referred to as "dunite veins") (Nicolas et al. (2000b) and references therein). Angular contacts, harzburgite blocks trapped between dunite veins, and stockwork-like geometry suggest a hydrofracturing origin for the magmatic dikes from which the dunitic reaction zones formed (Fig. 2b right). The crosscutting nature of these veins indicates they post-date

170 asthenospheric flow, but several examples of partially tectonically transposed dunite veins suggest 171 they also could form in the flowing mantle. Centimetric dunites parallel to the foliation are also 172 observed in the MMS (henceforth "dunite bands") (insert in Fig. 2b), possibly representing extreme 173 examples of transposed veins. All the MMS dunites, even those in harzburgite diapirs, represent a 174 negligible, unmappable fraction of the mantle volume. 
175 (3) Basal banded unit (BBU): This zone often hosts abundant, mainly concordant dunitic bands (Fig.

176 2c). These are usually centimeters to meters thick, rarely up to 20 meters, with the largest being 177 mappable locally at the $1 / 10000$ scale. They are sometimes composed of opx-poor harzburgite 178 instead of dunite. Coarse-grained samples sometimes occur between fine-grained ones (Table A.2) 179 and at the top of the unit, suggesting that the transition from the low-temperature to the high180 temperature domain is irregular, and that the BBU is thicker than the low-temperature domain. In the 181 Wadi Tayin and Nakhl-Rustaq massifs, the top of this unit, where coarse-grained asthenospheric deformation is preserved, includes 3-20 meter "blobs" of dunite, often with several dunite veins 183 branching into them, exactly as drawn by Bartholomew (1983). Such blobs are rare in the MMS (none 184 in our cross-sections). The concentration of dunitic bands in the BBU is poorly understood. Lippard et 185 al. (1986) suggested that ophiolite thrust-related extreme deformation of scattered dunite bodies in 186 the mantle section could explain the basal dunite banding; however, this would not explain the higher 187 dunite content in this section relative to the MMS, and the fact that parts of the banding, as well as 188 the dunitic blobs, display asthenospheric deformation textures.

189 An exceptional fourth type of dunite is exposed in the Batin area, consisting of a dunite body $>9$ 190 kilometers long, 2 kilometers wide and several hundred meters thick (Fig. 1), evident on the USGS 191 Wadi Tayin geological map and clearly visible in the field and on aerial photographs. This body was 192 sampled by the ICDP Oman Drilling Project and several dedicated studies, including our own, are 193 ongoing. Apart from the Batin area, no dunite larger than 30 meters, or similar to those at the base of 194 the ophiolite, was found in the MMS. This is true even in the diapiric areas, thought to represent feeding zones for the overlying crust. 
(a) Moho Transition zone (MTZ) at the summit of the mantle section

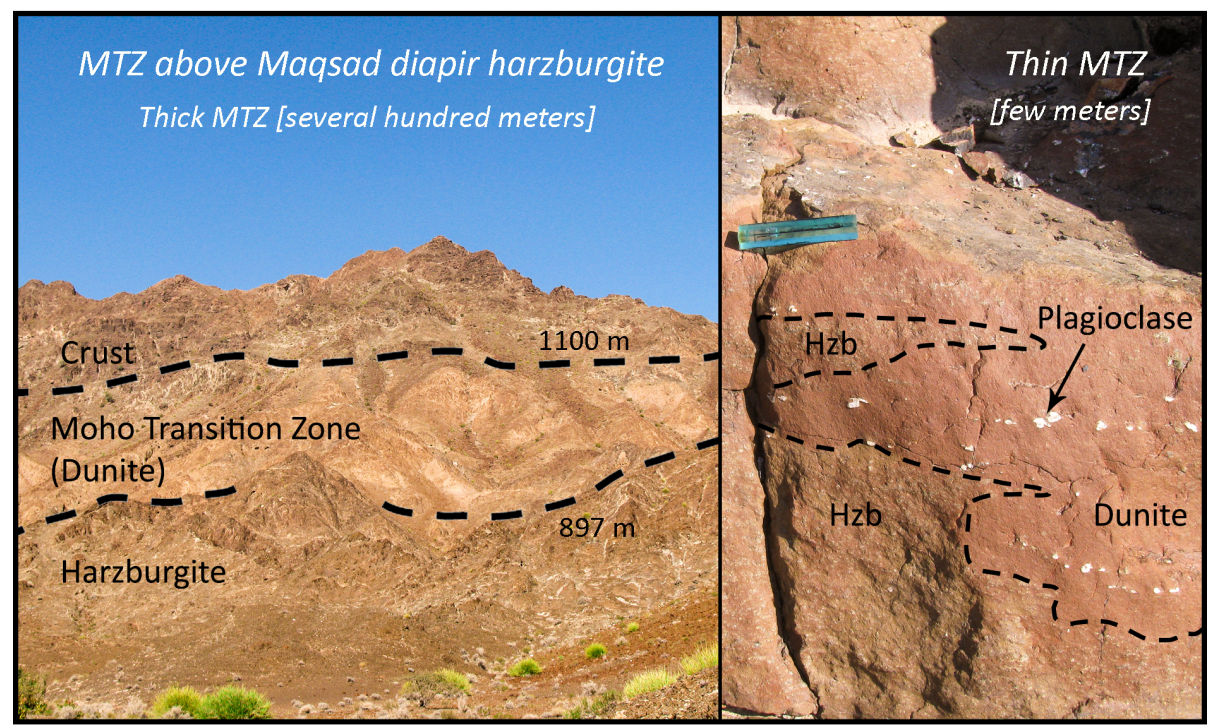

(b) Sporadic dykes in the main mantle section

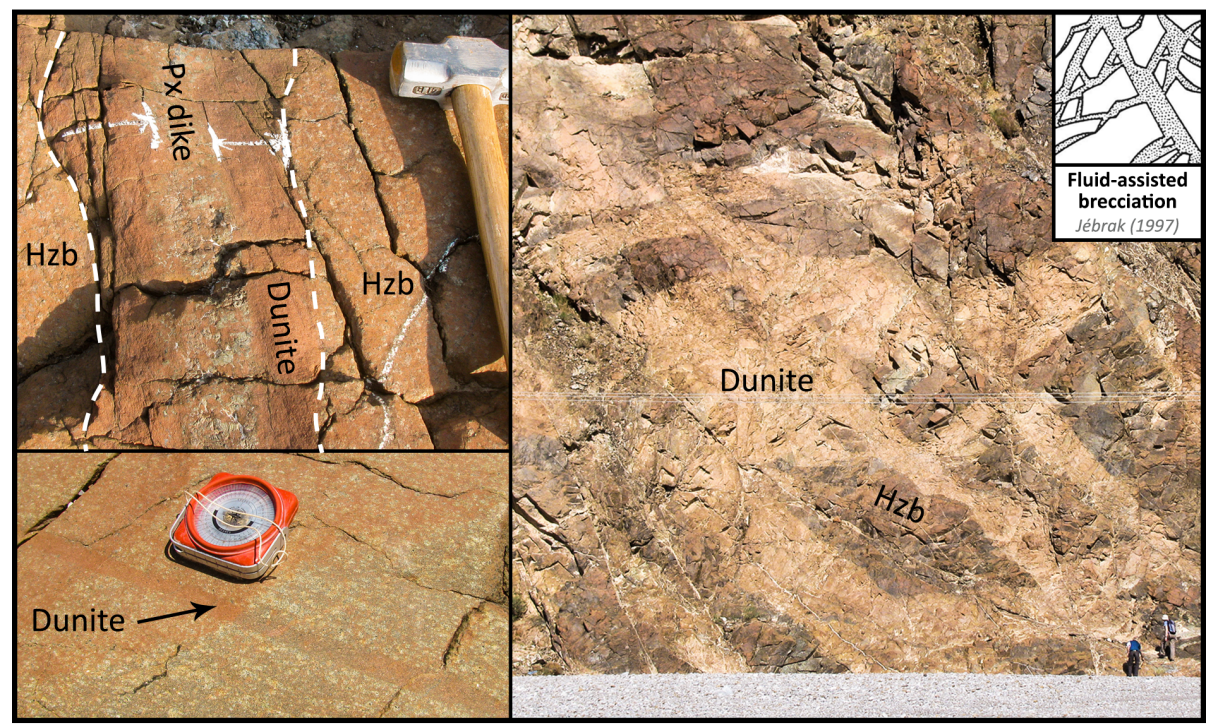

(c) Abundant concordant dunite bands at the base of the ophiolite

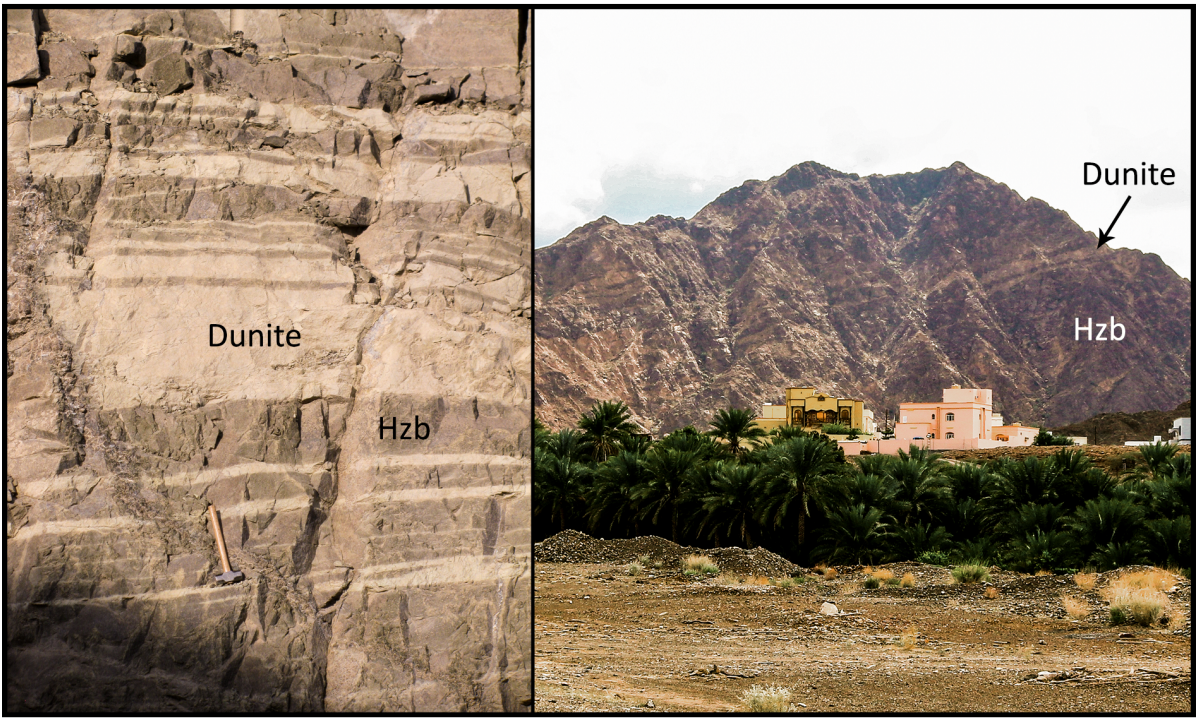


197 Fig. 2. Field photographs illustrating the three types of dunite observed in the mantle section of the SE

198 Oman ophiolite. (a) Moho Transition Zone (MTZ): Left, landscape-view of the thick dunitic MTZ just 199 beneath the crust in the Maqsad diapir region; Right, plagioclase-impregnated dunite of the thin MTZ

200 from the Nakhl-Rustaq massif in contact with residual harzburgite. (b) Sporadic veins in the main 201 mantle section (MMS) of the Nakhl-Rustaq massif: Left, thin pyroxenite dike with dunite reaction zone; 202 insert, concordant dunite band. Right, cross-cutting plurimetric dunite veins (16OD1) to compare with 203 insert showing sketch of a breccia hydrofracture network from Jébrak (1997). (c) Abundant concordant 204 dunitic bands at the base of the ophiolite: Left, succession of dunitic and harzburgitic bands in the 205 basal section from the northern Sumail massif; Right, landscape-view of the basal banded unit in the 206 Wadi Tayin massif. Hzb, harzburgite. 
208 Samples were selected from the three types of dunite (19 from 81 collected dunites, chosen for 209 freshness and variety) and host harzburgite (20 from 140 collected harzburgites) in the mantle 210 sections of the Nakhl-Rustaq, Sumail, Wadi Tayin and Haylayn massifs (Fig. 1; UTM coordinates in 211 Tables A.2-3). In six cases, dunite and harzburgite were collected in close proximity ( $<1$ meter) (Table 212 A.1). Sampling localities include both off-axis (e.g. Nakhl-Rustaq and Wadi Tayin massifs, Mansah 213 diapir in Sumail massif) and on-axis (e.g. Maqsad diapir in Sumail massif) settings.

214 Dunite structural data and petrographic descriptions of all analyzed samples are given in Tables A.1-2 215 (complementary descriptions of non-analyzed samples in Table A.9). Harzburgites are moderately to highly serpentinized and have coarse-grained porphyroclastic textures, except for four fine-grained samples from the BBU. Dunites are moderately to highly serpentinized, with higher degrees of serpentinization in the MTZ and the BBU. Sulfides are very rare and small in both lithologies. Medium to high-temperature porphyroclastic and granular textures are observed among all three types of dunite. Grain size, spinel abundance, crystal shape and serpentinization degree do not vary systematically, making it difficult to distinguish different dunite types simply from examination of hand specimens or thin sections. Nevertheless, basal dunites (1) never contain plagioclase, and (2) often 223 contain orthopyroxene relics. Our dunitic samples include seven pure dunites $(98.0-99.5 \%$ ol and $<0.5$ $\left.2242.0 \%_{\mathrm{sp}_{\mathrm{p}}}\right)$, eight containing pyroxene relics $\left(<1.5 \%_{\mathrm{p}_{\mathrm{x}}}\right)$, three impregnated with plagioclase and/or 225 pyroxene, and one olivine troctolite.

226 Whole-rock major and trace element compositions (Tables A.3-5) were determined respectively by the 227 SARM at CRPG using an ICP-OES iCap6500 and at Géosciences Montpellier (AETE-ISO University of 228 Montpellier, France) using an Agilent 7700X quadrupole ICP-MS. After chemical separation, Os isotopic 229 analyses (Tables A.6-8) were done at CRPG by NTIMS using a Finnigan MAT262 mass spectrometer. 230 Details of analytical methods are provided in the Supplementary Material. 


\section{Variations in major element and Os isotope compositions with structural}

233 Harzburgites from both the main and basal sections have Mg\# mostly from 0.900 to 0.916 and Os concentrations from 2.27 to $6.29 \mathrm{ppb}$ (Fig. 3b, 4a; Table 1 and Tables A.3, 6-7). Basal harzburgites generally have lower $\mathrm{Al}_{2} \mathrm{O}_{3}(0.39-0.63$ wt.\%) than MMS harzburgites (0.48-0.96 wt.\%), except for two samples (16OL27B and 16OL29), whose compositions (0.92 and 1.21 wt.\%) approach those of clinopyroxene-bearing harzburgites from Godard et al. (2000) (Fig. 3a). Plagioclase-impregnated, orthopyroxene-poor harzburgite $160 \mathrm{D} 5 \mathrm{C}$ from the uppermost MMS displays the highest FeO (8.76 wt.\%) and lowest Os content of all of the harzburgites (Fig. 3b, 4a). Values of ${ }^{187} \mathrm{Os} /{ }^{188} \mathrm{Os}_{95 \mathrm{Ma}}$ vary from 0.1131 to 0.1345 , with most between 0.12 and 0.13 , and no systematic differences are observed between MMS and basal harzburgites (Fig. 4a and Table 1). These values span nearly the entire global abyssal peridotite range (Becker and Dale, 2016), with the least radiogenic samples having Redepletion model ages $\left(\mathrm{T}_{\mathrm{RD}}\right) \sim 2.2 \mathrm{Ga}$ (using Primitive Upper Mantle (PUM) evolution curve of Meisel et al. (2001)). $\mathrm{T}_{\mathrm{RD}}$ ages are obtained by comparing measured ${ }^{187} \mathrm{Os} /{ }^{188} \mathrm{Os}$ values directly with the mantle evolution curve, implicitly assuming Re concentration equals zero in residual peridotite after melt extraction. However, this assumption is often false, as moderate melt extraction leaves peridotites with non-zero Re contents. Therefore, $\mathrm{T}_{\mathrm{RD}}$ ages are always minimum values that could dramatically underestimate true melt extraction ages. Nevertheless, the $T_{R D}$ ages $>0.5 \mathrm{Ga}$ of most of the harzburgites imply that they experienced some melt extraction hundreds of million years before

250 possible remelting beneath the Oman spreading center.

251 Dunites have highly variable compositions correlating with their structural contexts (Fig. 3, 4b-c):

252 (1) MTZ dunites have generally low Mg\# (0.897-0.920; mean: 0.904) with higher $\mathrm{Al}_{2} \mathrm{O}_{3}$ (0.09-1.71 wt.\%) 253 and lower Os concentration (0.39 to $1.17 \mathrm{ppb}$ ) than most other dunites. Their ${ }^{187} \mathrm{Os}^{188}{ }^{18 \mathrm{Os}_{95 \mathrm{Ma}} \text { ratios }}$ 254 (0.1415 to 0.1490) are higher than the estimated PUM value ( 0.1289 at $95 \mathrm{Ma}$; Meisel et al. (2001)) 255 and coherent with those of Oman MTZ chromitites (Ahmed et al., 2006). Plagioclase-impregnated 256 dunite $100 \mathrm{M} 25$ and especially troctolite $160 \mathrm{~L} 34 \mathrm{~B}$ are enriched in magmatophile elements $(\mathrm{Fe}, \mathrm{Al}, \mathrm{Ca})$ 
257 (Fig. 3). The Os concentration and ${ }^{187} \mathrm{Os} /{ }^{188} \mathrm{Os}_{95 \mathrm{Ma}}$ of dunite $100 \mathrm{M} 25$ do not differ from those of other 258 MTZ dunites, but troctolite 160 L34B is less radiogenic (0.1319) and has a higher Os concentration 259 (2.30 ppb) (Fig. 4b).

260 (2) Relative to MTZ dunites, most MMS dunites display a restricted range of Mg\# (0.893-0.908; mean: 261 0.902), lower $\mathrm{Al}_{2} \mathrm{O}_{3}$ (mostly 0.11-0.51 wt.\%), higher Os concentration (1.12 to $5.95 \mathrm{ppb}$ ) and lower $262{ }^{187} \mathrm{Os}^{188}{ }^{18 \mathrm{Os}_{95 \mathrm{Ma}}}(0.1249$ to 0.1330$)$. One unusual sample (16OD9A) located $\sim 1 \mathrm{~km}$ below the MTZ has 263 atypical Os characteristics (11.80 ppb Os; $\left.{ }^{187} \mathrm{Os} /{ }^{188} \mathrm{Os}_{95 \mathrm{Ma}}=0.1483\right)$ but an unexceptional major element 264 composition ( $\mathrm{Mg \# =} 0.905 ; \mathrm{Al}_{2} \mathrm{O}_{3}=0.33$ wt.\%). In MMS dunite/harzburgite pairs, the dunite is always 265 much more radiogenic than the harzburgite (Fig. 4c).

266 (3) Basal dunites display higher overall Mg\# (0.908-0.923; mean: 0.914) and lower $\mathrm{Al}_{2} \mathrm{O}_{3}$ ( $\leq 0.8$ wt.\%) 267 than the other dunites. Their Os concentrations vary substantially (0.77 to $7.17 \mathrm{ppb}$ ), while their $268{ }^{187} \mathrm{Os} /{ }^{188} \mathrm{Os}_{95 \mathrm{Ma}}$ ratios $(0.1165$ to 0.1280$)$ are similar to abyssal peridotite values. Unlike in the MMS, 269 paired dunites and harzburgites collected in the BBU have very similar isotope ratios.

270 When placed in the structural framework defined here, previous $\mathrm{Mg \# ,} \mathrm{Al}_{2} \mathrm{O}_{3}$, Os concentration and Os 271 isotope results from harzburgites and dunites of the Oman ophiolite (Godard et al., 2000; Hanghøj et 272 al., 2010; Senda et al., 2020; Xiong et al., 2020a,b) are consistent with these observations. 


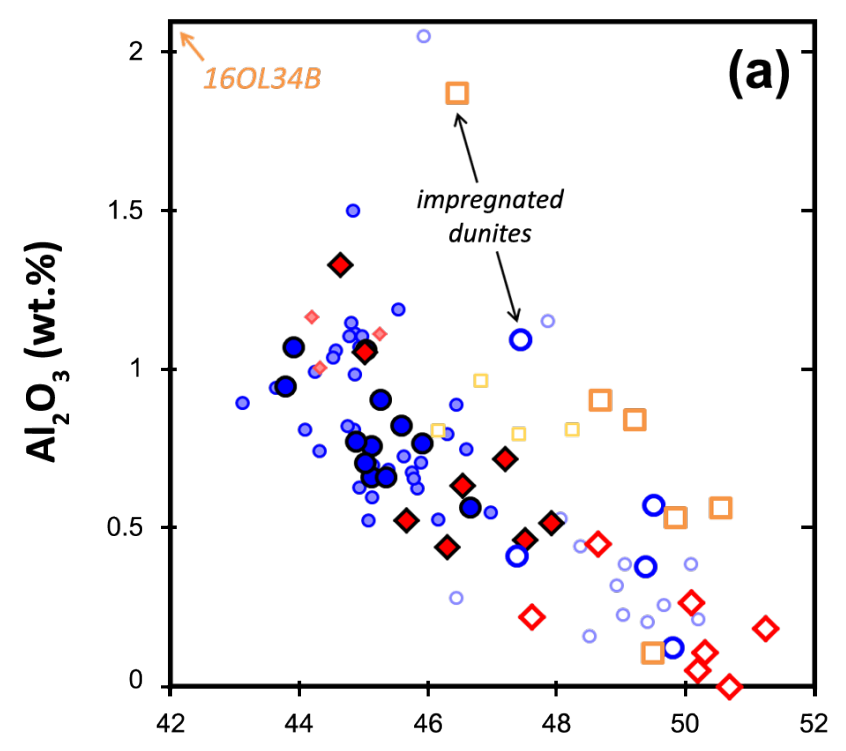

$\mathrm{MgO}$ (wt.\%)

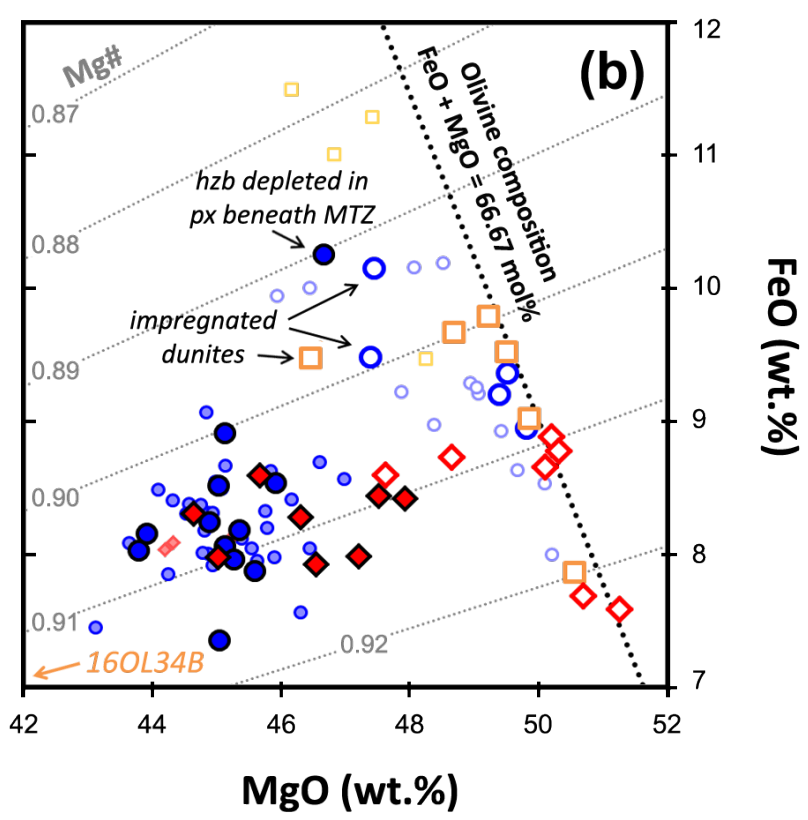

$\mathrm{MgO}$ (wt.\%)
This study

MTZ peridotites

$\square$ Dunite
Main mantle section (MMS) peridotites

- Harzburgite

O Dunite $\frac{\text { Basal mantle section peridotites }}{\diamond \text { Harzburgite }}$

$\diamond$ Dunite
Literature data

MTZ Dunite

- MMS Harzburgite

- MMS Dunite

$\diamond$ Basal Harzburgite

Fig. 3. Whole-rock major element compositions of harzburgites and the three types of dunite

275 recalculated on a volatile-free basis in (a) $\mathrm{Al}_{2} \mathrm{O}_{3}$ vs. $\mathrm{MgO}$ and (b) $\mathrm{FeO}$ vs. MgO diagrams. In panel (b),

276 dotted grey lines represent constant Mg\# values and the bold dotted black line shows the evolution of

277 olivine composition constrained by $\mathrm{FeO}+\mathrm{MgO}=66.67$ mol\% following Godard et al. (2000). In all

278 panels, olivine troctolite (16OL34B) plots outside of the graph area, with higher $\mathrm{Al}_{2} \mathrm{O}_{3}$ and lower $\mathrm{FeO}$

279 and MgO concentrations. Published Oman peridotite data are shown for comparison: MTZ dunites

280 (Godard et al., 2000); MMS dunites (Godard et al., 2000; Hanghøj et al., 2010); MMS harzburgites

281 (Godard et al., 2000; Hanghøj et al., 2010) and basal harzburgites (Godard et al., 2000). Attribution of

282 samples reported in the literature to the three domains defined in our study was based on their

283 geographic positions in the mantle section. 


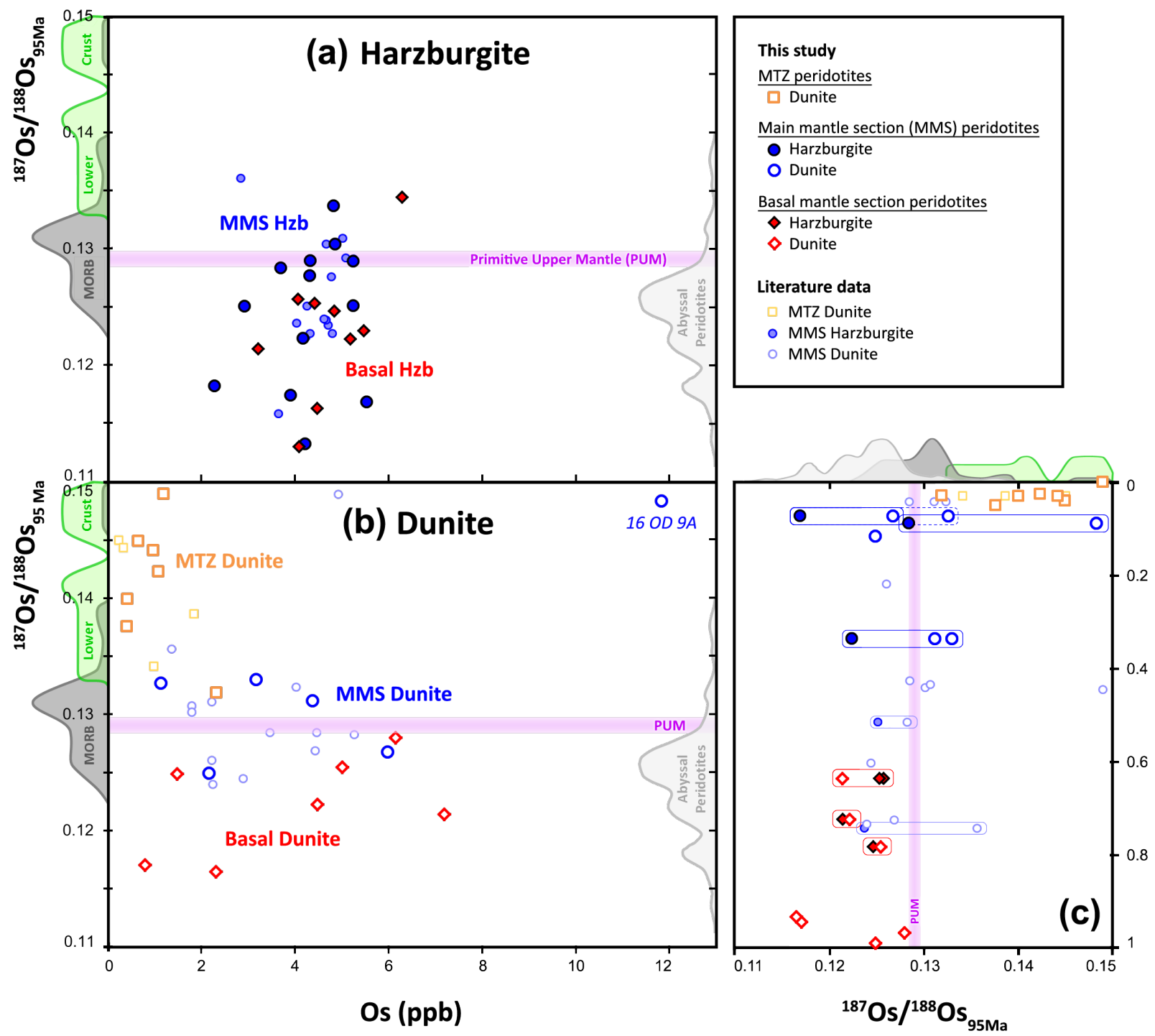

Fig. 4. Os isotope compositions of harzburgites and the three types of dunite. (a) ${ }^{187}$ Os ${ }^{188}{ }^{\text {Os }} s_{95 M a}$ vs.

286 [Os] in harzburgites; (b) ${ }^{187}$ Os $/{ }^{188} \mathrm{Os}_{95 \mathrm{Ma}}$ vs. [Os] in dunites; (c) Variation in dunite ${ }^{187} \mathrm{Os}^{188}{ }^{188} \mathrm{Os}_{95 \mathrm{Ma}}$ with approximate height in the stratigraphic section, normalized to the total height (Moho to base) of each section to allow comparison of samples from different cross-sections. Harzburgites taken adjacent to six of the dunites are also shown, with blue and red contours delimiting harzburgite-dunite pairs in the MMS and the BBU, respectively. Dunite $160 D 4 C$ (dashed blue contour) is associated with the $291160 D 4 D_{D u n / H z b}$ pair but was collected at a greater distance from the harzburgite $(30 \mathrm{~cm})$. In all panels, 292 light purple fields represent the estimated ${ }^{187} \mathrm{Os} /{ }^{188}$ Os ratio for the Primitive Upper Mantle (PUM) 293 ( 0.1289 at $95 \mathrm{Ma}$ ) (Meisel et al., 2001). Light grey, dark grey and green curves on both sides of the 294 diagrams show the probability density distributions of ${ }^{187} \mathrm{Os} /{ }^{188}$ Os ratios for abyssal peridotites 
297 are shown for comparison: MTZ dunites (Xiong et al., 2020a,b); MMS dunites (Hanghøj et al., 2010;

298 Xiong et al., 2020a,b) and MMS harzburgites (Hanghøj et al., 2010) (symbols as in Fig. 3), with

299 attribution to each mantle domain based on geographic positions in the mantle section.

300 Table 1. Mg\#, Re and Os concentrations and Os isotope compositions of the studied Oman peridotites

\begin{tabular}{|c|c|c|c|c|c|c|c|c|c|c|c|}
\hline Sample & Massif & Lithology & Hzb/Dun pairs & $\begin{array}{l}\text { Normalized height } \\
\text { in the section }\end{array}$ & $\mathrm{Mg} \#$ & $\begin{array}{l}{[\mathrm{Os}]} \\
(\mathrm{ppb})\end{array}$ & $\begin{array}{l}{[\mathrm{Re}]} \\
(\mathrm{ppb})\end{array}$ & ${ }^{187} \mathrm{Re} /{ }^{188} \mathrm{Os}$ & $\left({ }^{187} \mathrm{Os} /{ }^{188} \mathrm{Os}\right)_{\mathrm{m}}$ & $\left({ }^{187} \mathrm{Os} /{ }^{188} \mathrm{Os}\right)_{95 \mathrm{Ma}}$ & $2 \sigma$ error \\
\hline \multicolumn{12}{|c|}{ Moho Transition Zone (MTZ) peridotites } \\
\hline 10 OM 25 & Sumail (Maqsad) & impregnated dunite & & 0.030 & 0.897 & 0.399 & 0.114 & 1.376 & 0.14214 & 0.13996 & 0.00055 \\
\hline $10 \mathrm{OM} 45 \mathrm{C}$ & Sumail (Maqsad) & dunite & & 0.030 & 0.900 & 0.947 & 0.050 & 0.255 & 0.14456 & 0.14415 & 0.00064 \\
\hline $18 \mathrm{OK} 26$ & Sumail (Maqsad) & dunite & & 0.040 & 0.920 & 0.628 & 0.409 & 3.149 & 0.14993 & 0.14494 & 0.00086 \\
\hline 10 OM 5C* & Sumail (Mansah) & dunite & & 0.025 & 0.908 & 1.063 & & & 0.14235 & 0.14115 & 0.00052 \\
\hline 10 OM 5C-d & & & & & & & 0.168 & 0.760 & & & \\
\hline 07 OD 1 & Sumail (Mansah) & dunite & & 0.050 & 0.900 & 0.390 & 0.199 & 2.462 & 0.14151 & 0.13761 & 0.00057 \\
\hline 16 OL $11 B$ & Wadi Tayin & pure dunite & & 0.000 & 0.903 & 1.173 & 0.033 & 0.137 & 0.14922 & 0.14900 & 0.00085 \\
\hline $16 \mathrm{OL} 34 \mathrm{~B}$ & Wadi Tayin & olivine troctolite & & 0.028 & 0.899 & 2.305 & 0.053 & 0.111 & 0.13209 & 0.13192 & 0.00200 \\
\hline \multicolumn{12}{|c|}{ Main mantle section (MMS) peridotites } \\
\hline 16 OD 5C & Nakhl-Rustaq & depleted harzburgite & & 0.007 & 0.890 & 2.274 & 0.448 & 0.948 & 0.11976 & 0.11826 & 0.00199 \\
\hline 16 OD 5D & Nakhl-Rustaq & harzburgite & & 0.007 & 0.916 & 4.211 & 0.152 & 0.174 & 0.11362 & 0.11334 & 0.00116 \\
\hline $16 O D 7$ & Nakhl-Rustaq & harzburgite & & 0.053 & 0.909 & 2.921 & 0.025 & 0.042 & 0.12517 & 0.12510 & 0.00160 \\
\hline $16 \mathrm{OD} 4 \mathrm{D}_{\mathrm{Hzb}}$ & Nakhl-Rustaq & harzburgite & 16 OD $4 D_{\text {Dun }}$ & 0.073 & 0.900 & 5.519 & 0.358 & 0.312 & 0.11741 & 0.11691 & 0.00054 \\
\hline 16 OD $9 \mathrm{C}$ & Nakhl-Rustaq & harzburgite & 16 OD 9A & 0.089 & 0.908 & 3.691 & 0.130 & 0.170 & 0.12871 & 0.12844 & 0.00134 \\
\hline 16 OD 2 & Nakhl-Rustaq & harzburgite & & 0.241 & 0.907 & 4.314 & 0.500 & 0.559 & 0.12990 & 0.12902 & 0.00114 \\
\hline 16 OD $1 \mathrm{~A}$ & Nakhl-Rustaq & harzburgite & $16 \mathrm{OD} 1 \mathrm{~B}$ & 0.337 & 0.906 & 4.164 & 0.599 & 0.693 & 0.12350 & 0.12241 & 0.00059 \\
\hline 16 OD 10 & Nakhl-Rustaq & harzburgite & & 0.419 & 0.906 & 4.855 & 0.381 & 0.378 & 0.13112 & 0.13052 & 0.00106 \\
\hline 11 OD $15 \mathrm{~A}$ & Sumail & harzburgite & & 0.280 & 0.912 & 3.894 & 0.152 & 0.187 & 0.11782 & 0.11753 & 0.00057 \\
\hline 07 OD 24 & Sumail & harzburgite & & 0.254 & 0.907 & 4.826 & 0.460 & 0.459 & 0.13451 & 0.13378 & 0.00051 \\
\hline 07 OD 27B & Sumail & harzburgite & & 0.344 & 0.904 & 4.314 & 0.221 & 0.247 & 0.12817 & 0.12778 & 0.00052 \\
\hline 07 OD 8C & Sumail & harzburgite & & 0.150 & 0.910 & 5.246 & 0.379 & 0.348 & 0.12961 & 0.12906 & 0.00066 \\
\hline 07 OD 8C-d & & & & & & 5.228 & 0.321 & 0.295 & 0.12570 & 0.12523 & 0.00056 \\
\hline 16 OD $4 C$ & Nakhl-Rustaq & impregnated dunite (vein) & $\left(16\right.$ OD 4D $\left.\mathrm{D}_{\mathrm{Hz}}\right)$ & 0.073 & 0.893 & 1.120 & 0.305 & 1.312 & 0.13474 & 0.13267 & 0.00106 \\
\hline $16 \mathrm{OD} 4 \mathrm{D}_{\text {Dun }}$ & Nakhl-Rustaq & impregnated dunite (vein) & 16 OD 4D $\mathrm{D}_{\mathrm{Hzb}}$ & 0.073 & 0.899 & 5.954 & 0.414 & 0.335 & 0.12729 & 0.12676 & 0.00055 \\
\hline 16 OD 9A & Nakhl-Rustaq & pure dunite (band) & 16 OD 9C & 0.089 & 0.905 & 11.802 & 0.431 & 0.177 & 0.14862 & 0.14834 & 0.00063 \\
\hline 16 OD $1 B$ & Nakhl-Rustaq & dunite (vein) & 16 OD $1 \mathrm{~A}$ & 0.337 & 0.904 & 3.145 & 0.087 & 0.134 & 0.13324 & 0.13303 & 0.00065 \\
\hline 16 OD 1B-d & & & & & & 4.353 & 0.094 & 0.104 & 0.13135 & 0.13119 & 0.00061 \\
\hline 16 OD 31 & Wadi Tayin & dunite (band) & & 0.116 & 0.908 & 2.147 & 0.910 & 2.043 & 0.12814 & 0.12491 & 0.00215 \\
\hline \multicolumn{12}{|c|}{ Basal peridotites } \\
\hline 16 OD $13 \mathrm{C}$ & Nakhl-Rustaq & harzburgite & 16 OD $13 B$ & 0.637 & 0.909 & 4.415 & 0.415 & 0.453 & 0.12607 & 0.12536 & 0.00054 \\
\hline 16 OD $13 C-d$ & & & & & & 4.076 & 0.379 & 0.448 & 0.12647 & 0.12577 & 0.00058 \\
\hline 16 OL 25 & Wadi Tayin & harzburgite & & 0.724 & 0.905 & 6.289 & 0.081 & 0.062 & 0.13464 & 0.13454 & 0.00088 \\
\hline 16 OL $26 \mathrm{~B}$ & Wadi Tayin & harzburgite & 16 OL $26 \mathrm{~A}$ & 0.724 & 0.910 & 3.214 & 0.022 & 0.032 & 0.12151 & 0.12146 & 0.00148 \\
\hline 16 OL 27B & Wadi Tayin & harzburgite & 16 OL $27 \mathrm{~A}$ & 0.784 & 0.910 & 4.843 & 0.314 & 0.312 & 0.12522 & 0.12472 & 0.00107 \\
\hline 16 OL $27 \mathrm{C}$ & Wadi Tayin & harzburgite & & 0.784 & 0.913 & 4.097 & 0.046 & 0.053 & 0.11314 & 0.11306 & 0.00121 \\
\hline $16 \mathrm{OL} 28 \mathrm{~B}$ & Wadi Tayin & harzburgite & & 0.860 & 0.909 & 4.481 & 0.168 & 0.180 & 0.11659 & 0.11630 & 0.00113 \\
\hline 16 OL 29 & Wadi Tayin & harzburgite & & 0.872 & 0.906 & 5.187 & 0.169 & 0.157 & 0.12256 & 0.12231 & 0.00100 \\
\hline $16 \mathrm{OL} 24$ & Wadi Tayin & harzburgite & & 0.878 & 0.913 & 5.475 & 0.221 & 0.194 & 0.12335 & 0.12305 & 0.00097 \\
\hline 16 OD 13B & Nakhl-Rustaq & dunite (band) & 16 OD $13 C$ & 0.637 & 0.923 & 7.169 & 0.158 & 0.106 & 0.12155 & 0.12139 & 0.00054 \\
\hline 16 OD 15E & Nakhl-Rustaq & dunite (band) & & 0.934 & 0.911 & 2.291 & 0.106 & 0.223 & 0.11688 & 0.11653 & 0.00070 \\
\hline 16 OD $18 B$ & Sumail & dunite (band) & & 0.969 & 0.908 & 6.134 & 0.018 & 0.014 & 0.12800 & 0.12798 & 0.00060 \\
\hline 16 OD $19 A$ & Sumail & pure dunite (band) & & 0.946 & 0.910 & 0.774 & 0.066 & 0.413 & 0.11773 & 0.11707 & 0.00120 \\
\hline $16 \mathrm{OL} 26 \mathrm{~A}$ & Wadi Tayin & dunite (band) & $16 \mathrm{OL} 26 \mathrm{~B}$ & 0.724 & 0.909 & 4.460 & 0.014 & 0.015 & 0.12227 & 0.12225 & 0.00112 \\
\hline 16 OL 27A & Wadi Tayin & dunite (band) & 16 OL 27B & 0.784 & 0.912 & 4.998 & 0.079 & 0.077 & 0.12560 & 0.12548 & 0.00102 \\
\hline $1411 \mathrm{E}$ & Haylayn & pure dunite (band) & & 0.990 & 0.922 & 1.474 & 0.157 & 0.512 & 0.12573 & 0.12492 & 0.00053 \\
\hline
\end{tabular}

Os isotopic compositions in whole rock were analyzed at the CRPG laboratory in Nancy (France) using N-TIMS (Finnigan MAT 262) and MC-ICP-MS (Neptune +). All uncertainties are $2 \sigma a$ and include all recognized sources of uncertainty, including in-run analytical precision, reproducibility of standard analyses, uncertainties related to the variability of the blank and its isotope composition, uncertainties related to the age correction $(95 \mathrm{Ma}$ ). Samples belonging to harzburgite/dunite pairs collected in close proximity ( $<1$ meter) are indicated. For each sample, an approximate estimation of its height in the mantle section was obtained by normalizing to the total section height to compare samples from different cross-sections. Duplicate analyses were performed for several samples (noted "-d") and UB-N standard. More details are presented in the Supplementary Material.

* For 10 OM 5 C sample, $\left(^{187} \text { Os }{ }^{188} \text { Os }\right)_{95}$ ma was calculated using Re compositions of its duplicate.

$\mathrm{Mg} \#=\mathrm{Mg} /(\mathrm{Mg}+\mathrm{Fe}) \mathrm{at} ; \mathrm{Hzb}=$ harzburgite; Dun = dunite.

301 


\section{Discussion}

303 Our coupled geochemical and structural observations underscore three findings:

304 (1) Throughout the mantle section, harzburgite $\mathrm{Mg \# ,} \mathrm{Al}_{2} \mathrm{O}_{3}$ contents, Os concentrations and isotopic compositions span a range comparable to that of abyssal peridotites (Becker and Dale, 2016) (Fig. 3, 4a). Dunites display more variable compositions linked to their structural contexts, with ${ }^{187} \mathrm{Os} /{ }^{188} \mathrm{Os}_{95 \mathrm{Ma}}$ and $\mathrm{Al}_{2} \mathrm{O}_{3}$ content increasing and $\mathrm{Mg \#}$ generally decreasing from the $\mathrm{BBU}$ through the $\mathrm{MMS}$ to the MTZ (Fig. 3, 4b-c).

(2) In the BBU, dunite Os isotope compositions closely resemble those of adjacent harzburgites (Fig. 4c). In contrast, dunites in the overlying MMS have more radiogenic compositions than associated 311 harzburgites.

(3) In the MTZ, dunite ${ }^{187} \mathrm{Os} /{ }^{188} \mathrm{Os}_{95 \mathrm{Ma}}$ ratios are much more radiogenic than those of abyssal peridotites or even MORB (Gannoun et al., 2016), and dunite Os concentrations are low (Fig. 4b-c).

\subsection{Evidence against seawater contamination}

We first consider whether the radiogenic compositions of the MTZ dunites result from hydrothermal circulation of seawater, which has high ${ }^{187} \mathrm{Os} /{ }^{188} \mathrm{Os}(\sim 0.51-0.57$ in the mid-Cretaceous; Ravizza et al. (2001)) and could modify ${ }^{187}$ Os $/{ }^{188}$ Os in oceanic peridotites (discussion in Becker and Dale (2016)). Given the very low Os concentration of seawater ( $10 \mathrm{fg} / \mathrm{g}$; Levasseur et al. (1998)), water/rock ratios required to significantly change Os compositions of peridotites are extremely high $(>1000)$. In ophiolitic peridotites, water/rock ratios are almost always <100 (McCulloch et al., 1981), so significant modification of ${ }^{187} \mathrm{Os} /{ }^{188}$ Os should be rare.

Our samples have water contents ( $\mathrm{LOI}<15.42 \%$, most $<12 \%$ ) typical of serpentinized peridotites. No correlation is observed between $\mathrm{LOI}$ values, highly mobile element (Rb, $\mathrm{Cs}$, Ba and $\mathrm{U}$ ) abundances or Th/U ratios (Fig. A.2 and Tables A.3-4) and Os isotope composition. As shown in Fig. A.2b, interaction of typical peridotite $\left({ }^{187} \mathrm{Os} /{ }^{188} \mathrm{Os}=0.124\right.$; [Os] from 0.4 to $\left.6 \mathrm{ppb}\right)$ with seawater cannot produce the radiogenic Os compositions found in MTZ dunites without decreasing Th/U ratios far below observed levels, implying that the Os isotope signatures of our samples reflect essentially magmatic processes. 


\subsection{Os isotope evolution during melt-rock interaction}

\subsubsection{First order considerations}

330

Dunite bodies are generally viewed as reaction products formed as melts migrate through host harzburgite, dissolving pyroxene and precipitating olivine. Focused melting experiments show that melt fractions of $0.25-0.30$ are required to dissolve all pyroxenes at $0.5 \mathrm{GPa}$ (Lambart et al., 2009). However, once all pyroxenes have been removed, the amount of additional melt migrating through a dunite body is difficult to quantify. Signatures of incompatible element tracers, which are dramatically less abundant in dunite than in melt, will be rapidly overprinted by equilibration with the liquid during melt percolation. In contrast, peridotites, including dunites, have higher Os concentrations than mantle melts. Thus, as melts equilibrate with peridotite during melt percolation, dunite Os concentration and ${ }^{187} \mathrm{Os} /{ }^{188} \mathrm{Os}$ should change slowly and progressively, allowing this element to serve as a tracer of the extent of melt-peridotite interaction.

To roughly estimate the proportion of melt needed to obtain the initial isotopic compositions of the three types of dunite, we first consider a two-component mixture between peridotite $\left({ }^{187} \mathrm{Os} /{ }^{188} \mathrm{Os}=\right.$ 0.124 , typical of Oman harzburgites) and melt $\left(0.2 \mathrm{ppb} \mathrm{Os} ;{ }^{187} \mathrm{Os} /{ }^{188} \mathrm{Os}=0.150\right)$. The melt ${ }^{187} \mathrm{Os} /{ }^{188} \mathrm{Os}$ was chosen to be slightly more radiogenic than the MTZ dunites. This value is higher than those of all MORB and most arc lavas (except for extrusives with extremely low Os contents, whose isotope compositions are easily modified by assimilation of radiogenic crustal material; see data compilation in Bezard et al. (2021)). Results are shown for two peridotite Os concentrations (Fig. 5; details in Supplementary Material), representing typical harzburgite (4 ppb) and MTZ dunite (0.5 ppb). The peridotite ${ }^{187} \mathrm{Os} /{ }^{188} \mathrm{Os}$ ratio rises slowly with increasing melt fraction and is nearly unchanged at the melt fraction (0.25-0.30) needed to fully transform harzburgite to dunite. Much higher melt fractions, 0.75-0.96 and $\geq 0.94$ respectively using the assumed parameters, are needed to attain ${ }^{187} \mathrm{Os} /{ }^{188} \mathrm{Os}$ values of MMS ( 0.130) or MTZ ( 0.140) dunites. 


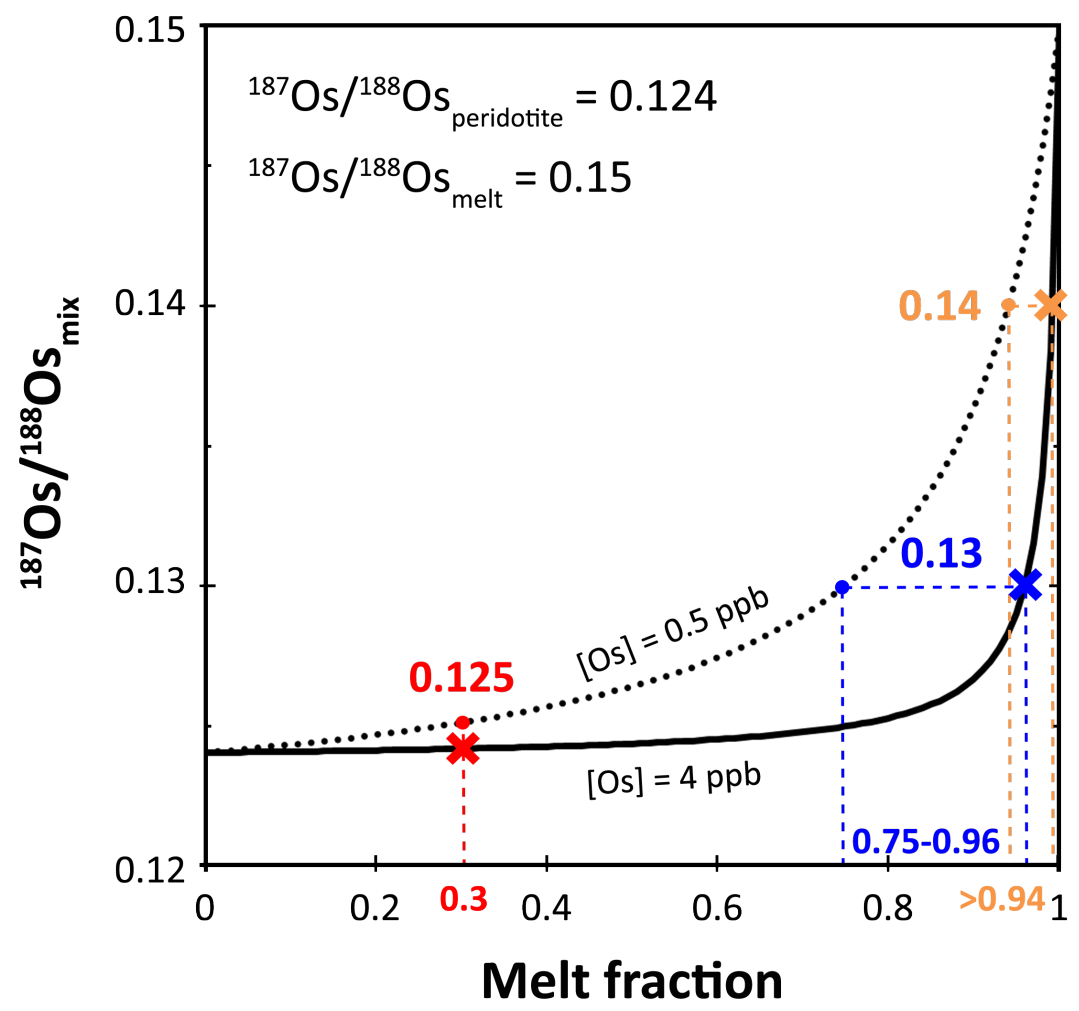

353 Fig. 5. Two-component mixture between peridotite $\left({ }^{187} \mathrm{Os} /{ }^{188} \mathrm{Os}=0.124\right)$ and melt $\left({ }^{187} \mathrm{Os} /{ }^{188} \mathrm{Os}=0.150\right.$; $354[\mathrm{Os}]=0.2 \mathrm{ppb}$ ) (cf. Supplementary Material). The two starting Os concentrations for the peridotite are 355 used to simulate a mixture of a typical harzburgite (4 ppb; continuous curve) and of a MTZ dunite (0.5 356 ppb; dotted curve) with the melt. Basal dunites (red) have Os isotope compositions similar to those of 357 harzburgites, suggesting low melt fractions. Higher melt fractions, 0.75-0.96 and $\geq 0.94$ respectively, 358 increase ${ }^{187}$ Os $/{ }^{188}$ Os to 0.130 (MMS dunite; blue) or 0.140 (MTZ dunite; orange). 
While two-component mixing models allow qualitative assessment of the melt fractions needed to produce the radiogenic compositions of MMS and MTZ dunites, melt percolation models taking the Os partition coefficients $\left(k_{d}\right)$ of the pertinent phases into account are more realistic. One critical point is the compatible behavior of Os in common mantle rocks partly due to its extremely chalcophile nature $\left(k_{d \text { in sulfide }} \sim 10^{6}\right.$ ) (Mungall and Brenan, 2014). During percolation of sulfide-undersaturated melts in the uppermost mantle, the sulfide fraction in the peridotite decreases progressively. As long as the peridotite contains sulfide, Os is trapped in the residue. When the peridotite loses its final trace of sulfide, the Os partition coefficient of the peridotite is likely to be lowered significantly causing Os concentration to decrease with continuing melt percolation. Concomitantly, if the percolating melts have a more radiogenic composition, the ${ }^{187} \mathrm{Os} /{ }^{188} \mathrm{Os}$ of the host peridotite increases gradually.

In a simple model, a representative elementary volume (cell) of harzburgite is flushed repeatedly by increments of $2 \%$ melt of a constant radiogenic composition (details in Supplementary Material). As in most more complex models (e.g. Vernières et al. (1997)), chemical and isotopic equilibrium with the peridotite is assumed to be attained after each melt increment is added. After equilibration, the melt moves out of the cell and is replaced by fresh melt of the original composition. We suppose that the 376 initial Os compositions of melt and harzburgite are the same as those used in the two-component 377 mixture, and that transformation of harzburgite to dunite occurs after interaction with $25-30 \%$ of 378 melt, corresponding to $10-15$ melt increments. For simplicity, we also consider that complete sulfide 379 removal is coincident with full transformation of harzburgite into dunite, i.e. when opx depletion is 380 complete. If sulfide exhaustion occurs slightly before or after transformation to dunite, the results will 381 not change substantively. In our model, the harzburgite contains $100 \mathrm{ppm}$ sulfide, equivalent to 40 382 ppm S, assumed to decrease to zero over 10 increments of $2 \%$ melt.

383 After each increment of new melt equilibrates with the peridotite, the Os isotope composition is 384 controlled by mass balance, while the new Os concentrations of the melt and the residual peridotite 
are controlled by the Os partition coefficients of the phases present. Osmium is strongly retained by

386 the residue as long as sulfides remain. As sulfur is removed into the silicate melt, the IPGE (Iridium-

387 group PGE: Os, Ir, Ru, Rh) are increasingly concentrated in the refractory sulfide residues, leading 388 eventually to exsolution of platinum group minerals (PGM) such as Ir-Os alloys (Fonseca et al., 2012). 389 Ir-Os alloys, laurites $\left(\mathrm{RuS}_{2}\right)$ and other PGM are probably the main hosts of Os in dunites and other sulfide-poor mantle peridotites (reviewed in Lorand and Luguet (2016) and O'Driscoll and GonzálezJiménez (2016)). In addition to PGM, experimental data (summarized in Brenan et al. (2016)) indicate that Ir and Ru are compatible in Cr-rich spinel, which constitutes $~ 1-3 \%$ of the dunite (Table A.2), and to a lesser extent in olivine, suggesting that Os could also be hosted by these phases. Thus, Os may behave as a moderately compatible element in dunite even after all sulfides have been removed. Nevertheless, dunites that have been fluxed by large quantities of magma have lower Os concentrations than most mantle harzburgites (Büchl et al., 2002), suggesting unsurprisingly that the compatibility of Os in peridotite is lowered in the absence of sulfide. Taking these observations into

398 consideration, we consider a bulk partition coefficient $\left(D_{O s}\right)$ of 2 for dunites, which are assumed to 399 have lost all of their original sulfide content. The effect of varying this value is explored below. Further 400 constraint of $D_{O s}$ will require a better understanding of the behavior and stability of Os-bearing PGM 401 during melt fluxing. 
403

Results of the model are compared with the data in Fig. 6. The model is obviously simplistic. The 404 harzburgitic protolith is treated as a single composition rather than the wide range of harzburgite 405 compositions observed in the ophiolite, likely explaining much of the mismatch with the data. 406 Similarly, incoming melt composition and $D_{O S}$, treated as constants, most probably vary with time. Nevertheless, this model provides a conceptual framework for examining the extent of melt-rock reaction experienced by each type of dunite. While the geometries and contexts of the three types of dunite are quite different, the melt-rock reaction process can be modeled in each case by melt fluxing 410 through a volume of rock, using the parameters given in the caption to Fig. 6.

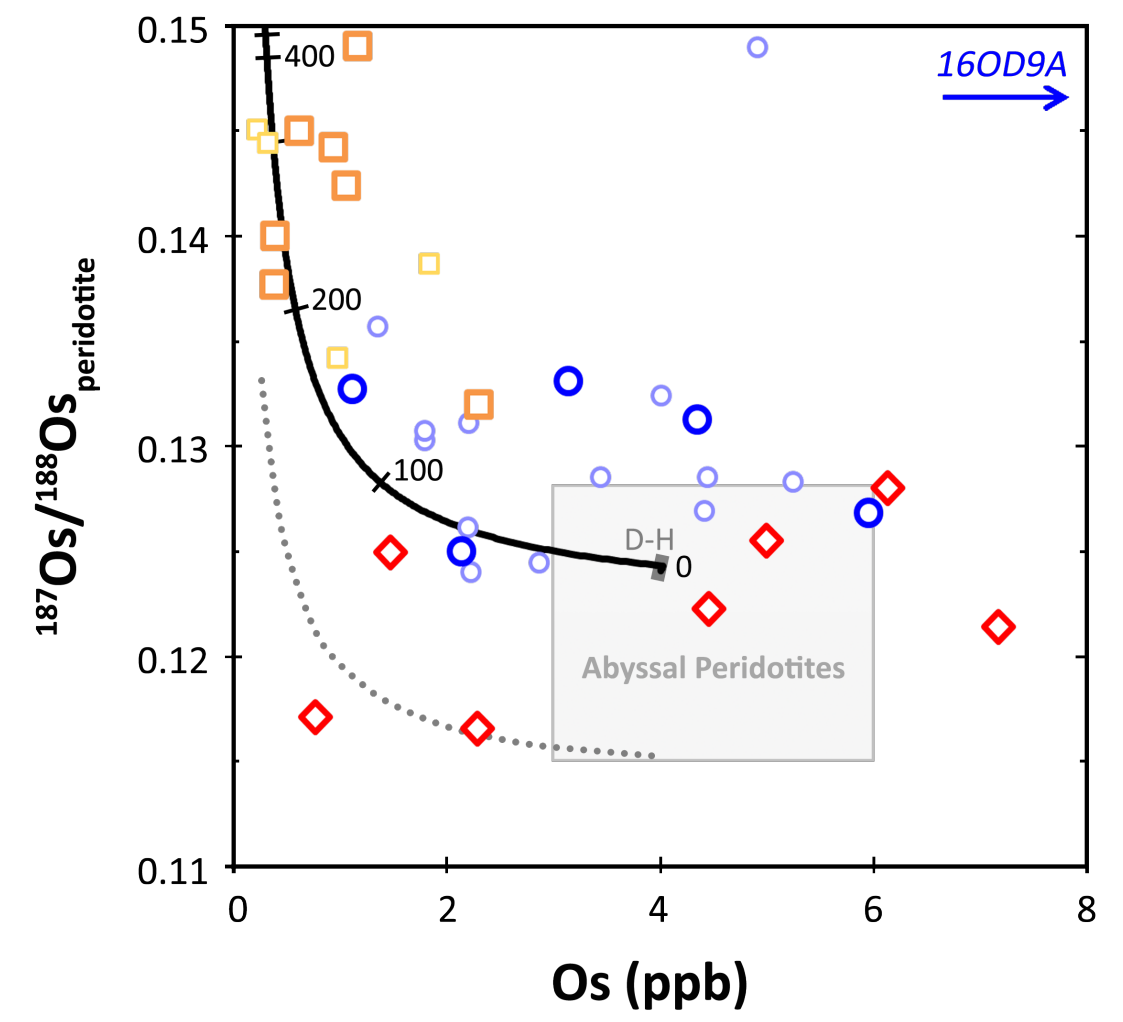

Fig. 6. Effect of percolation of radiogenic melt $\left({ }^{187} \mathrm{Os} /{ }^{188} \mathrm{Os}=0.150 ;[\mathrm{Os}]=0.2 \mathrm{ppb}\right)$ through a representative elementary volume (i.e., a single cell) of typical harzburgite $\left({ }^{187} \mathrm{Os} /{ }^{188} \mathrm{Os}=0.124 ;[\mathrm{Os}]=4\right.$ ppb). Black curve shows evolution of peridotite ${ }^{187}$ Os $/{ }^{188}$ Os vs. [Os] during this process. As repeated 415 increments of melt (taken here as 2\%) traverse the harzburgite, the pyroxenes will dissolve 416 progressively, resulting in dunite formation after $\sim 10-15$ increments have passed (zone indicated as D$417 H$ on diagram). Concomitantly, any sulfides present in the harzburgite will also be dissolved in the 
percolating melt, with complete sulfide dissolution assumed to approximately coincide with the transition from harzburgite to dunite. As Os will be retained as long as sulfide is present, Os concentrations will not start to decrease before this transition is nearly complete. In the example shown, the starting harzburgite is assumed to contain $100 \mathrm{ppm}$ sulfide ( $40 \mathrm{ppm} \mathrm{S}), k_{d, O s}=10^{6}$ for sulfide and $D_{O s}=2$ for dunite (see discussion of parameter choices in text and Supplementary Material). After transition to dunite, continued fluxing with repeated increments of melt (tick marks placed at $100,200,300$ and 400 increments on the curve) will cause the Os isotopic ratio and concentration to move from the starting position in the abyssal peridotite field along the black curve towards the higher ${ }^{187} \mathrm{OS} /{ }^{188} \mathrm{OS}_{95}$ ma ratios and lower Os concentrations found in the MTZ dunites. Dotted grey curve represents percolation of a different melt $\left([\mathrm{Os}]=0.2 \mathrm{ppb} ; \mathrm{MORB}-\mathrm{like}{ }^{187} \mathrm{Os} /{ }^{188} \mathrm{Os}=0.133\right.$ - Gannoun et al. (2016)), interacting with harzburgite with ${ }^{187} \mathrm{Os} /{ }^{188}$ Os towards the bottom of the abyssal peridotite range (Becker and Dale, 2016), possibly explaining low [Os] and unradiogenic compositions of two of the basal dunites. Os concentrations and initial Os isotope ratios for the three types of dunite are shown for comparison with the results of the melt percolation model (symbols as in Fig. 3). to lower the Os contents and raise the ${ }^{187} \mathrm{Os} /{ }^{188} \mathrm{Os}$ ratios of the initial harzburgite to the values ( 0.2$1.0 \mathrm{ppb}$ and $\left.{ }^{187} \mathrm{Os} /{ }^{188} \mathrm{Os}_{95 \mathrm{Ma}} \sim 0.138-0.149\right)$ observed in MTZ dunites. Such high melt/rock ratios are 435 consistent with the intense melt-peridotite interactions thought to occur in this zone (Boudier and 436 Nicolas, 1995; Rospabé et al., 2018).

437 In the underlying MMS, nearly all dunites have ${ }^{187} \mathrm{Os} /{ }^{188} \mathrm{Os}_{95 \mathrm{Ma}}$ in the range of $0.125-0.133$, and in each 438 pair studied, the dunites are more radiogenic than the associated harzburgite. For the same melt 439 composition, the degree of melt-rock interaction required to obtain MMS-like Os isotopic signatures is 440 smaller than for MTZ dunites (less than 150 increments of melt, corresponding to melt/rock ratios <3; 441 Fig. 6). This is consistent with dunite formation by wall-rock reaction in melt dikes traversing the MMS 442 (Fig. 2b, 7a), a process reported in other peridotitic bodies (Becker et al., 2001; Büchl et al., 2002). 443 Wall-rock reaction would not have significantly modified the composition of melt flowing rapidly 
444 through the center of the dike, because of the limited contact with the peridotite relative to the large 445 volume of melt. In one case, two dunites were collected in the reaction zone of the same dike. Dunite 446 16OD4C, sampled $\sim 30 \mathrm{~cm}$ from the dike edge and impregnated with plagioclase and clinopyroxene, 447 has a moderately radiogenic ${ }^{187} \mathrm{Os} /{ }^{188} \mathrm{Os}_{95}$ ma ratio $(0.1327)$. Clinopyroxene-impregnated dunite $448160 D 4 D_{\text {Dun, }}$ from the border with the host harzburgite $\left(160 D 4 D_{\mathrm{Hzb}}\right)$, is less radiogenic $(0.1268)$, 449 suggesting lesser degrees of melt-rock interaction than near the dike center (Fig. 7a). This dunite is 450 nevertheless more radiogenic than the harzburgite (0.1169). The unusual MMS dunite band 16OD9A, 451 with very high Os concentration (11.80 ppb) and very radiogenic ${ }^{187} \mathrm{Os} /{ }^{188} \mathrm{Os}_{95 \mathrm{Ma}}(0.1483)$ cannot be explained by this model and instead requires a specific mechanism of PGM or radiogenic sulfide precipitation. The Os isotopic composition of this sample is similar to the melt end-member used in the model, suggesting that such phases could have precipitated from magmas similar to those that interacted with harzburgite to form the MTZ and MMS dunites.

Individual basal dunites show Os isotope compositions in the abyssal peridotite range, indicating that each experienced much lower extents of melt-rock interaction than MTZ or MMS dunites $(<<100$ melt increments; Fig. 6), though, given the high proportion of dunite, the total melt flow through the BBU may have been quite high. Unlike the MMS dunites, BBU dunites have ${ }^{187} \mathrm{Os} /{ }^{188} \mathrm{Os}_{95 \mathrm{Ma}}$ ratios very 460 similar to those of adjacent harzburgites (Fig. 4c). They also have higher Mg\#s and lower $\mathrm{Al}_{2} \mathrm{O}_{3}$ 461 contents than MMS and MTZ dunites (Fig. 3), arguing for lesser degrees of interaction with fertile 462 melt. Furthermore, some sections include opx-bearing dunite and/or opx-poor harzburgite bands, 463 likely formed by small degrees of melt-rock interaction insufficient to fully dissolve orthopyroxene.

464 Two dunites have low Os concentrations coupled with very unradiogenic compositions, implying 465 formation from harzburgites with very low ${ }^{187} \mathrm{Os} /{ }^{188} \mathrm{Os}$ (though within the abyssal peridotite range) and perhaps interaction with less radiogenic melts than those required for MTZ dunites. 


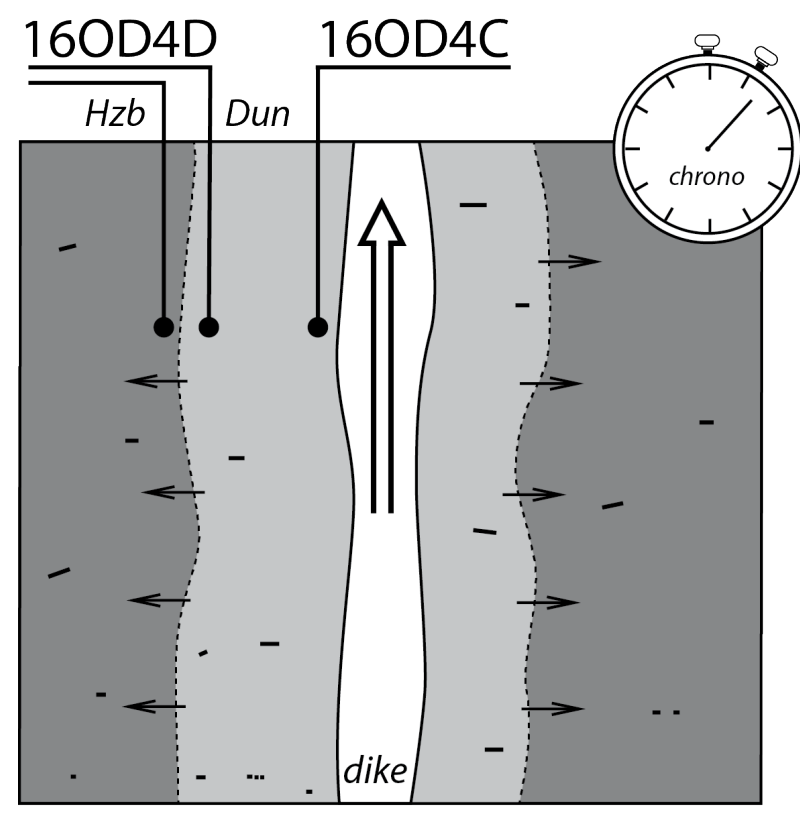

467

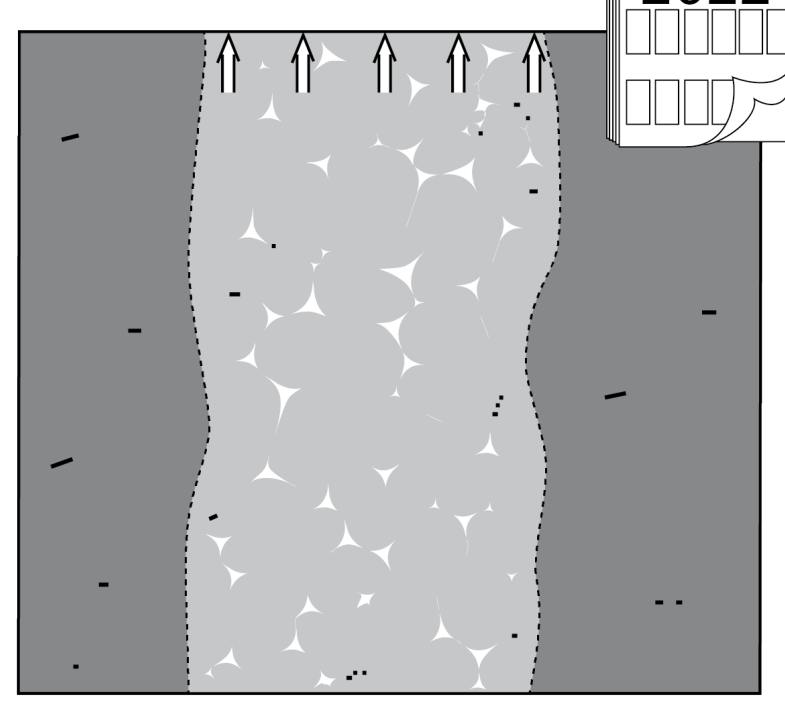

(b) Porous flow channel

Fig. 7. Schematic diagrams of two end-member melt transport mechanisms: hydrofracturing (a) vs. porous flow (b). White: melt; light grey: dunite; dark grey: harzburgite; small black lines: spinel grains marking the foliation. In panel (a), a hydrofracturing dike contains 100\% melt which travels fast (large arrow) and has a short life-span (weeks or months). Dikes produce a dunite reaction zone at their margins, that grows with time, and where the trace of foliation is preserved. In this case, samples at the center of the reaction zone (ie, closer to the dike) may have reacted with melt for a longer time and be more radiogenic than samples near the outside border of the reaction zone. This fits observations for MMS dunite samples $160 D 4 D_{\text {Dun }}$ and $160 D 4 C$, both associated with host harzburgite $16 D 4 D_{H z b}$. In panel (b), a porous flow channel is represented with a homogeneous distribution of 1-3\% melt, which travels slowly through the solid matrix along grain boundaries (short arrows) and has a long life-span (possibly steady-state). In this case, the dunite may fully equilibrate with the melt. 
480

481

482

483

484

485

486

The pertinence of the model parameter choices was evaluated by changing each parameter individually while holding the others constant (Fig. 8). The instantaneous melt fraction modifies the number of melt increments needed to obtain a given ${ }^{187} \mathrm{Os} /{ }^{188} \mathrm{Os}$ ratio, but has little effect on the corresponding melt/rock ratio (Fig. A.3) or on the relationship between ${ }^{187} \mathrm{Os} /{ }^{188}$ Os and [Os] (Fig. 8a). The Os bulk-rock partition coefficient after sulfide exhaustion affects the rapidity with which Os in the dunite is lost to the passing melts, and accordingly the rate at which ${ }^{187} \mathrm{Os} /{ }^{188} \mathrm{Os}$ is modified by repeated introduction of new melt (Fig. 8b and Fig. A.4). As discussed above, this parameter depends on the behavior and stability of rare PGM, and though modeled as a constant, probably changes during melt fluxing. To match both the Os isotope compositions and concentrations of the MTZ dunites, $D_{0 s}$ values between about 0.5 and 5 are required (Fig. $8 \mathrm{~b}$ ). For input melt of a fixed Os isotope composition, the Os concentration will control the number of iterations required to obtain a given ${ }^{187} \mathrm{Os} /{ }^{188} \mathrm{Os}$ ratio. The data field can be matched by melt Os concentrations ranging from about 0.02 to $0.5 \mathrm{ppb}$ (Fig. $8 \mathrm{c}$ and Fig. A.5). To produce MTZ dunites, the starting melt must have a ${ }^{187} \mathrm{Os} /{ }^{188}$ Os ratio of at least 0.15 (Fig. 8d and Fig. A.6), but melts with much higher ratios do not fit the data. The reasonableness of all of the successful parameters supports the plausibility of the model.

Fig. 8. Effect of varying (a) instantaneous melt fraction (f) $(0.5 \%, 2 \%$ and $4 \%)$, (b) Os bulk partition coefficient for dunite $\left(D_{O S}\right)(0.5,2,5)$, (c) melt Os concentration $(0.02,0.2$ and 0.5$)$ and (d) melt ${ }^{187} \mathrm{Os} /{ }^{188} \mathrm{Os}(0.13,0.15$ and 0.2$)$ on [Os] and ${ }^{187} \mathrm{Os} /{ }^{188} \mathrm{Os}$ of the peridotite in the single-cell melt percolation model shown in ${ }^{187}$ Os $/{ }^{188}$ Os vs. Os diagrams similar to Fig. 6. Data from our study for the three types of dunite, as well as published Oman dunite data are shown for comparison with initial Os isotope ratios (MTZ dunites - Xiong et al. (2020a,b); MMS dunites - Hanghøj et al. (2010) and Xiong et al. (2020a,b); attribution of literature data to dunite types based on geographic positions) (symbols as in Fig. 3). The chosen parameters in the model (black continuous curves) best fit the data. 
(a) $f$

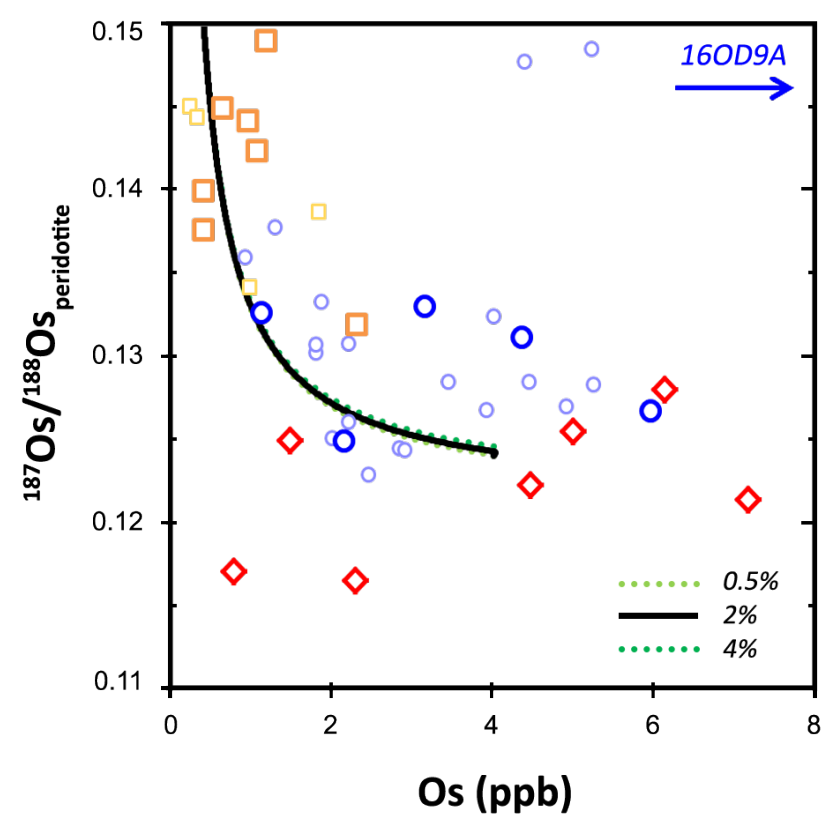

(c) $[\mathrm{Os}]_{\text {melt }}$

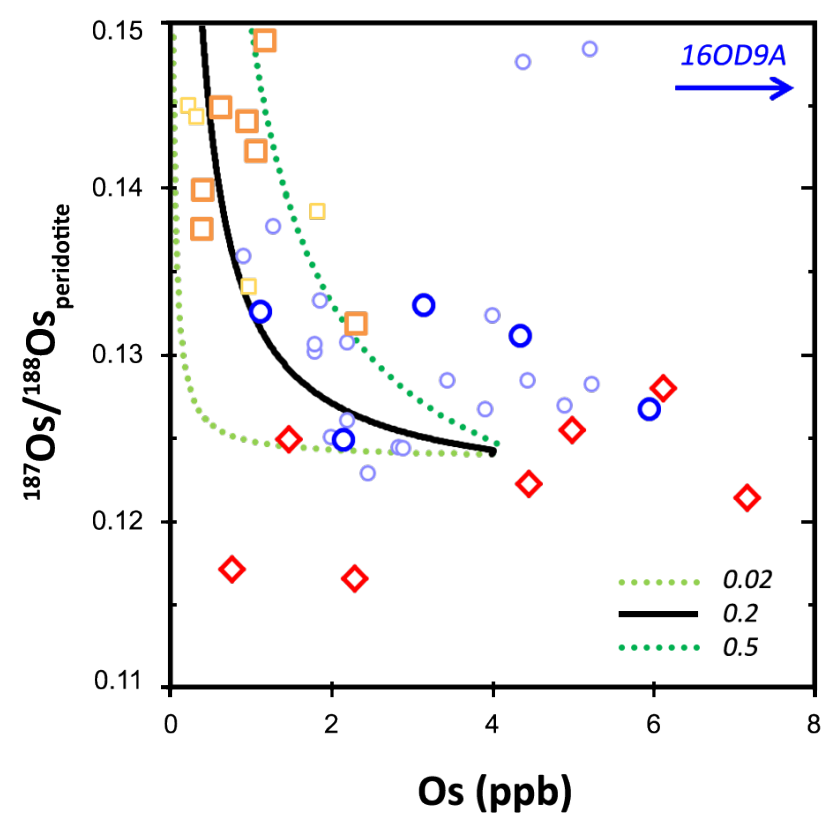

(b) $D_{\text {os }}$

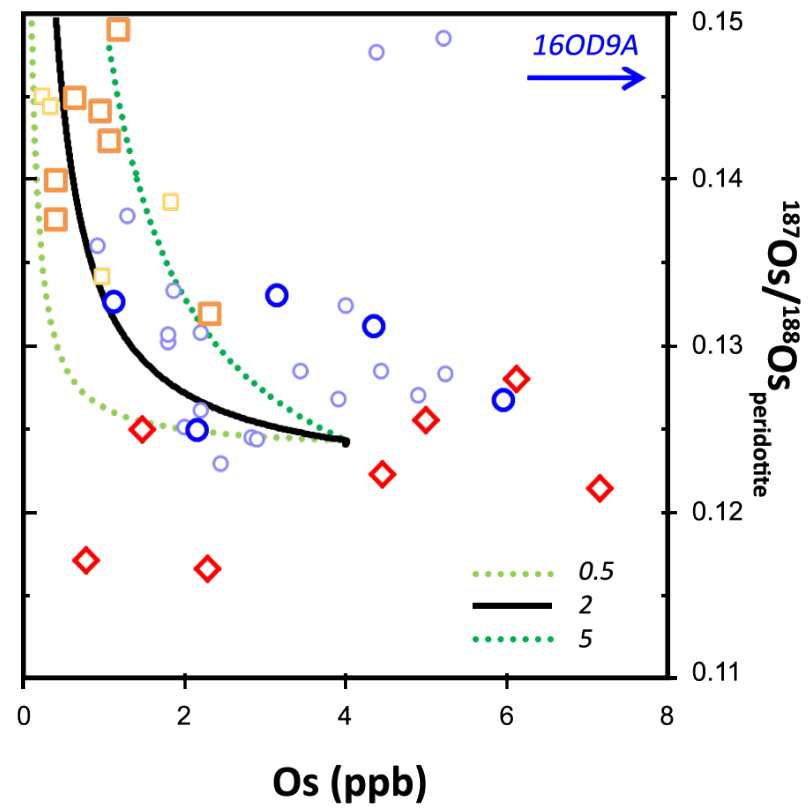

(d) ${ }^{187} \mathrm{Os} /{ }^{188} \mathrm{Os}$ melt

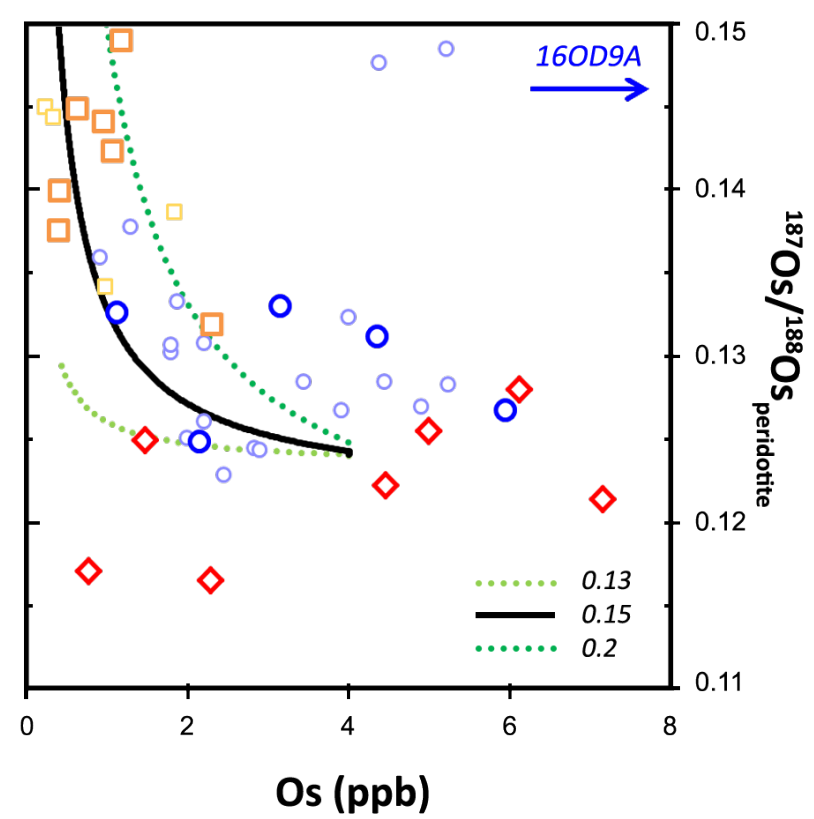

This study

$\square$ MTZ Dunite

O MMS Dunite

$\checkmark$ Basal Dunite
Literature data

MTZ Dunite

- MMS Dunite 
506 A melt more radiogenic than MORB is needed to explain the radiogenic character of many MMS and nearly all MTZ dunites. The high ${ }^{187} \mathrm{Os} /{ }^{188} \mathrm{Os}_{95 \mathrm{Ma}}$ ratios of the MTZ dunites are in good agreement with the ${ }^{187} \mathrm{Os} /{ }^{188} \mathrm{Os}_{95 \mathrm{Ma}}(\sim 0.142)$ of the Oman lower crust (Peucker-Ehrenbrink et al., 2012). Two sources of radiogenic melt are possible: ancient recycled oceanic crust (cf. pyroxenites; Sergeev et al. (2014)) or a downgoing slab (Becker et al., 2004). We cannot exclude either possibility, but the first case would require an unusual concentration of ancient pyroxenites in the mantle source, probably unrepresentative of heterogeneity in the upper mantle, as radiogenic values similar to those of MTZ dunites are rare in MORBs (Fig. 4). A slab-related source (effective during the main accretion phase of the Oman oceanic crust) seems more consistent with a suprasubduction setting for the Oman ophiolite, as proposed by Guilmette et al. (2018) and MacLeod et al. (2013). Regardless of its origin, the radiogenic nature of the melt is fortunate, as this allows us to trace the extent of melt-rock reaction in the different types of dunite.

518 A mechanism is needed to transport the radiogenic melt to the upper MMS and the MTZ. In one 519 commonly accepted model (Kelemen et al., 1995), the melt is transported by porous flow in dunite channels. Once the olivine-rich channels are established, the melt is protected from equilibration with the surrounding peridotite, but equilibrates with the dunite through which it travels (Fig. 7b). To consider whether this mechanism is consistent with our Os results, we model a dunite channel as a stack of reaction cells, each similar to that described above (Fig. 9a and details in Supplementary material). Each increment of fresh radiogenic melt enters the bottom cell and equilibrates with the peridotite, and then migrates upwards into the overlying cell and is replaced by a new melt increment 526 with the original composition. In this idealized model, the melt leaving this bottom cell will have a 527 much less radiogenic Os composition than the entering melt, because of the strong buffering effect of 528 the Os-rich peridotite (Fig. 9b). Similarly, the ${ }^{187} \mathrm{Os} /{ }^{188} \mathrm{Os}$ ratios of the overlying cells will be 529 successively less affected by melt interaction, with the ratio of the uppermost cell being hardly 530 modified at all (Fig. 9c). Therefore, melt leaving the dunite channel will have a ${ }^{187}$ Os $/{ }^{188}$ Os ratio close 531 to that of the original harzburgite from which the dunite formed (Fig. 9c). This implies that melts that 
532 have traveled through such channels, equilibrating with the dunite along the way, cannot retain the

533 highly radiogenic compositions needed to explain the high ${ }^{187} \mathrm{Os} /{ }^{188} \mathrm{Os} \mathrm{s}_{95 \mathrm{Ma}}$ ratios of the MTZ dunites

534 and the overlying lower crust. Instead, a mechanism without (or with little) equilibration with dunite

535 or harzburgite is needed to bring melts with a radiogenic Os signature from depth towards the Moho.

536 This lack of equilibration suggests rapid transfer of large melt volumes through the upper mantle

537 section, also proposed by Kogiso et al. (2004) to explain the existence of linear correlations between

$538 \mathrm{Os}$ and $\mathrm{Sr}, \mathrm{Nd}$ and $\mathrm{Pb}$ isotopes in some ocean island basalts. The quantitative constraint that

539 preservation of radiogenic Os compositions places on melt migration rates will depend on the

540 geometry of melt pathways and on Os diffusion coefficients. While there are few experimental

541 constraints on the latter, on theoretical grounds, Kogiso et al. (2004) estimated Os diffusion

542 coefficients in olivine to be similar to those of $\mathrm{Sr}$ and $\mathrm{Pb}$.

543 In addition to the melt brought to the MTZ through a rapid process, some melt may have percolated

544 through the harzburgite in mantle diapirs (Godard et al., 2000; Lorand et al., 2009). Coexistence of two

545 transport processes could be consistent with modeling of melt migration beneath mid-ocean ridges

546 based on U-series isotope systematics (Elkins et al., 2019). However, any melt percolating slowly

547 through harzburgite will acquire the non-radiogenic isotope composition of the peridotite, of which no

548 trace is found in the MTZ dunites. Such a scenario would require the melts traveling rapidly to have

549 had an even more radiogenic composition before mixing in the MTZ with melts that may have traveled

550 slowly. 
peridotite : $[\mathrm{Os}]=4 \mathrm{ppb}$ and ${ }^{187} \mathrm{Os} /{ }^{188} \mathrm{Os}=0.124$

\section{Melt/rock ratio}

(a)

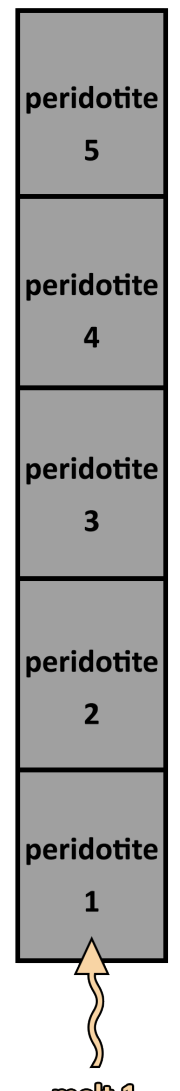

melli?

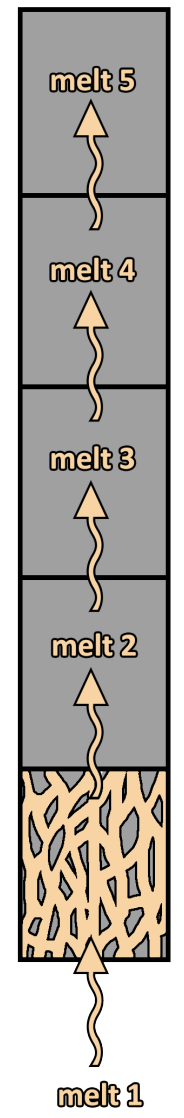

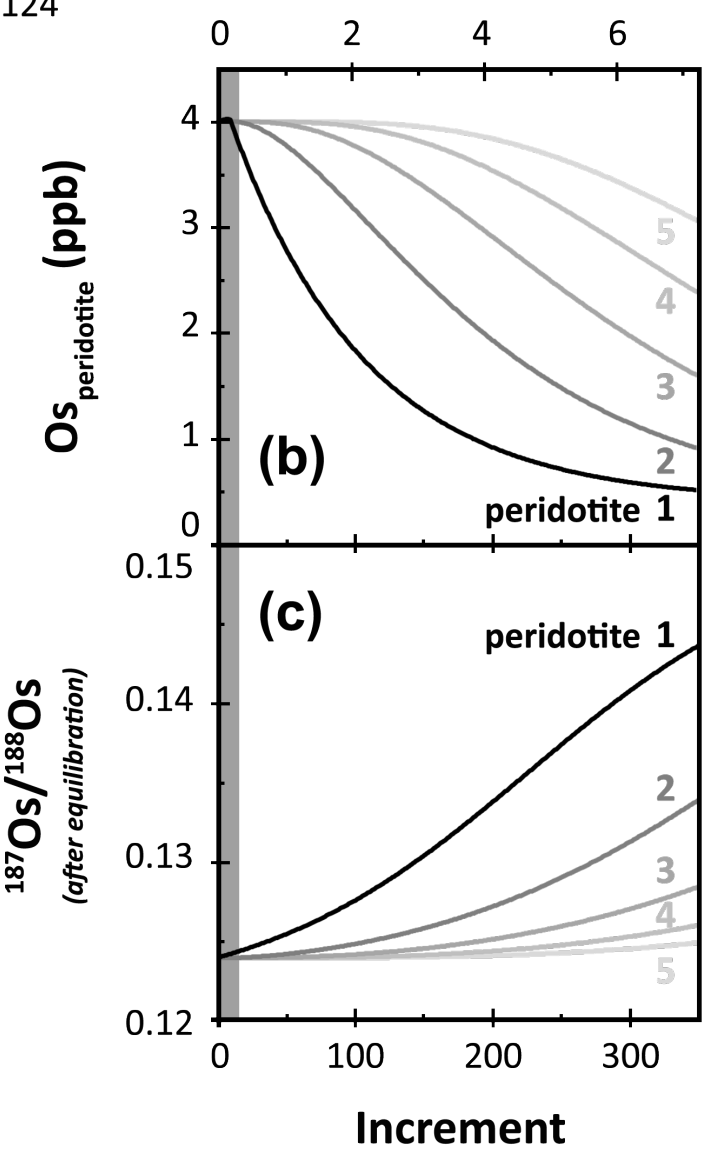

mellig : $[\mathrm{Os}]=0.20 \mathrm{ppb}$ and ${ }^{187} \mathrm{Os} /{ }^{188} \mathrm{Os}=0.15$

Fig. 9. Multi-cell model (see text) showing Os evolution during melt percolation through dunite channel developed in harzburgite. Starting Os compositions and sulfide fractions for harzburgite and melt are

554 the same as those in Fig. 6. Panel (a) depicts melt percolation through a five-cell peridotite column.

555 Melt enters the bottom cell and equilibrates with peridotite. After equilibration the melt and peridotite

556 will have the same isotopic composition. The melt then moves into the overlying cell as a fresh melt

557 increment enters the bottom cell; this process continues up the column. Compositions of peridotite cells

558 (black to light grey curves) vs. melt increment are shown in (b) [Os] and (c) ${ }^{187}$ Os ${ }^{188}$ Os; grey band on

559 left represents harzburgite not yet transformed into dunite. The results of the model for the lowermost

560 cell correspond to those of the single-cell melt percolation model shown in Fig. 6. Due to the strong

561 buffering effect of the Os-rich peridotite, the Os isotope compositions of the peridotite cells will be

562 successively less affected by melt interaction during the progressive ascent of the melt through the

563 channel. The compositions of the uppermost cell are hardly modified at all. 
The radiogenic Os composition of the MTZ dunites and overlying lower crust implies that they cannot have been fed by melts percolating through and equilibrating with a network of coalescing dunite channels. This inference is consistent with the scarcity of several meter thick dunites throughout the MMS. These observations contrast with the common view that large tabular dunites are frequent throughout the mantle section, as first expressed in the schematic diagram of Lippard et al. (1986). In the southern massifs of the Oman ophiolite, dunites are abundant in only three areas: (1) the MTZ, which structural, petrographic and geochemical evidence (Boudier and Nicolas, 1995; Godard et al., 2000; Koga et al., 2001; Rospabé et al., 2018) suggest formed in situ, while the overlying crust was still partially molten; (2) the BBU above the metamorphic sole; (3) the vicinity of the spectacular, yet atypical, giant Batin dunite body. In contrast, dunites are very rare even in the cores of mantle diapirs, thought to represent magmatic feeder zones for the overlying crust. The model of porous melt transport in vertical dunite channels (Kelemen et al., 1995) would predict the existence of large vertical dunite roots beneath the thick MTZ in these areas. Yet, such dunite conduits have not been found within any of the mantle diapirs. Alternatively, it has been proposed that upwardly migrating melts pool along a permeability barrier (e.g. the top of the melting region, the base of the lithosphere or the locus of plagioclase crystallization) and then migrate laterally, "uphill", along this boundary towards the ridge axis through porous flow channels or as "porosity waves" (Hebert and Montési, 2010; Sparks and Parmentier, 1991). At first glance, the basal dunite bands could correspond to the geometry suggested by this model. However, their Os isotope compositions are equivalent to those of the surrounding harzburgite, indicating they did not serve as pathways for the much more radiogenic melts that reached the MTZ and the lower crust.

If, as the geochemical and structural data indicate, melt did not migrate to the Moho through dunite channels, either vertically or along a putative permeability barrier, how was it transported? It appears to have traveled rapidly across the mantle section, possibly leaving very little chemical and isotopic imprint, except perhaps as small dunite reaction zones similar to those developed at the margins of the later cross-cutting veins (Fig. 2b, 7a). If such dunites formed while the mantle was still flowing 
591 under asthenospheric conditions, they could have been transposed and stretched. These dunites may 592 be difficult to identify now, or may correspond to the rare thin concordant bands observed in the 593 MMS (insert in Fig. 2b and Table A.1). The modeling of Stevenson (1989) and the experimental results 594 of Daines and Kohlstedt (1994) predict the formation of veins in the melting mantle. Rapid melt 595 transport through hydrofractures in the asthenosphere is a physically complex process (Richardson, 596 1998; Rubin, 1995), whose viability remains to be better established, but this process would fit our 597 structural and geochemical data. 


\section{Conclusions}

599 Dunite is distributed in the mantle section of the southeastern Oman ophiolite in three distinct 600 domains: (1) the Moho Transition Zone, a horizontal dunitic melt storage and reaction zone at the 601 summit of the mantle section, representing by far the largest volume of dunite; (2) the harzburgitic 602 main mantle section, just below the MTZ, crosscut by sporadic dikes rimmed by dunitic reaction zones 603 and rarer concordant bands; and (3) the basal banded unit, with many concordant dunitic bands 604 above the metamorphic sole.

605 Though these three types of dunite cannot be distinguished petrographically, their Os isotope 606 compositions are strongly correlated with their structural context. Basal dunites, like harzburgites 607 throughout the massifs, have ${ }^{187} \mathrm{Os} /{ }^{188} \mathrm{Os}_{95 \mathrm{Ma}}$ ratios in the range of abyssal peridotites, while the 608 dunitic veins and bands of the MMS have variable but somewhat more radiogenic compositions. 609 Critically, MTZ dunites have highly radiogenic Os isotope compositions, similar to those of the 610 overlying lower crust. Such compositions are inconsistent with models that call on melt transport to 611 the ridge by porous flow through dunite channels, as the high ${ }^{187} \mathrm{Os} /{ }^{188}$ Os ratios of the Os-poor melts 612 would be erased by equilibration with the unradiogenic compositions of the Os-rich dunites through 613 which they travel. Furthermore, the absence of thick vertical dunite bodies in mantle diapirs, thought 614 to represent magmatic feeder zones for the overlying crust, also argues that dunite channels are not 615 the dominant pathway of melt transport to the ridge. Thus, our results reveal the need for a process, 616 possibly hydrofracturing, that can rapidly bring radiogenic melts from the source region to the Moho 617 without significant equilibration with dunite or harzburgite of the surrounding mantle. 
619 We are very grateful to C. Zimmermann for her helpful assistance during Re-Os chemistry and isotope 620 analyses by N-TIMS and MC-ICP-MS. We also thank C. Parmentier for her help with chemistry, D. 621 Cividini and A. Schumacher for their technical support during MC-ICP-MS sessions, the SARM staff for 622 whole-rock major element analyses, C. Martin (Géosciences Montpellier) and L. Causse (AETE-ISO platform, OSU-OREME/Université de Montpellier) for their assistance during whole-rock trace element chemical preparation and analysis by quadrupole ICP-MS, C. Prigent for providing her samples from the Haylayn massif and E. Grellier for her petrographic observations during her Master. Informal discussions and contributions during fieldwork from F. Boudier, S. Singh and D. Levy were also highly appreciated. We thank B. O'Driscoll and H. Becker for their thorough and constructive reviews.

628 Financial support was provided by the TelluS Program of CNRS/INSU. We are finally highly grateful to 629 the Ministry of Commerce and Industry, Sultanate of Oman, for its hospitality and its permission to 630 undertake field sampling in Oman.

\section{Author Contributions}

D. Klaessens, D. Jousselin and L. Reisberg participated in fieldwork. D. Jousselin provided geological 633 context. C. Aupart completed initial analyses. D. Klaessens completed most of the analyses and wrote 634 the initial manuscript. L. Reisberg supervised Re-Os analyses and modeling. M. Godard oversaw trace 635 element analyses. D. Klaessens, L. Reisberg and D. Jousselin discussed the results and their 636 implications. All authors assisted in the final revisions to the manuscript.

\section{CRediT author statement}

638 Delphine Klaessens: Conceptualization, Methodology, Formal analysis, Validation, Investigation, 639 Visualization, Writing - Original Draft, Writing - Review \& Editing

640 Laurie Reisberg: Conceptualization, Methodology, Investigation, Writing - Review \& Editing, 641 Supervision, Funding acquisition 
642

David Jousselin: Conceptualization, Investigation, Writing - Review \& Editing, Supervision, Funding

643 acquisition

644 Marguerite Godard: Validation, Writing - Review \& Editing, Supervision

645 Claire Aupart: Formal analysis, Investigation, Writing - Review \& Editing

\section{$646 \quad$ Competing Interests statement}

647 None of the authors have competing interests.

$648 \quad \underline{\text { References }}$

649

650

651

652

653

654

655

656

657

658

659

660

661

662

663

664

665

666

1. Ahern, J.L., Turcotte, D.L., 1979. Magma migration beneath an ocean ridge. Earth Planet. Sci. Lett. 45, 115-122. https://doi.org/10.1016/0012-821X(79)90113-4

2. Ahmed, A.H., Hanghøj, K., Kelemen, P.B., Hart, S.R., Arai, S., 2006. Osmium isotope systematics of the Proterozoic and Phanerozoic ophiolitic chromitites: In situ ion probe analysis of primary Osrich PGM. Earth Planet. Sci. Lett. 245, 777-791. https://doi.org/10.1016/j.epsl.2006.03.021

3. Alabaster, T., Pearce, J.A., Malpas, J., 1982. The volcanic stratigraphy and petrogenesis of the Oman ophiolite complex. Contrib. to Mineral. Petrol. 81, 168-183. https://doi.org/10.1007/BF00371294

4. Bartholomew, I.D., 1983. The primary structures and fabrics of the upper mantle and lower crust from ophiolite complexes. The Open University, Milton Keynes.

5. Becker, H., Carlson, R.W., Shirey, S.B., 2004. Slab-derived osmium and isotopic disequilibrium in garnet pyroxenites from a Paleozoic convergent plate margin (lower Austria). Chem. Geol. 208, 141-156. https://doi.org/10.1016/j.chemgeo.2004.04.009

6. Becker, H., Dale, C.W., 2016. Re-Pt-Os isotopic and highly siderophile element behavior in oceanic and continental mantle tectonites. Rev. Mineral. Geochemistry 81, 369-440. https://doi.org/10.2138/rmg.2016.81.7

7. Becker, H., Shirey, S.B., Carlson, R.W., 2001. Effects of melt percolation on the Re-Os systematics of periodites from a Paleozoic convergent plate margin. Earth Planet. Sci. Lett. 188, 107-121. 
8. Bezard, R., Turner, S., Schaefer, B., Yogodzinski, G., Hoernle, K., 2021. Os isotopic composition of western Aleutian adakites: Implications for the Re/Os of oceanic crust processed through hot subduction zones. Geochim. Cosmochim. Acta 292, 452-467. https://doi.org/10.1016/j.gca.2020.10.009

9. Boudier, F., Coleman, R.G., 1981. Cross section through the peridotite in the Samail Ophiolite, southeastern Oman Mountains. J. Geophys. Res. Solid Earth 86, 2573-2592. https://doi.org/10.1029/JB086iB04p02573

10. Boudier, F., Nicolas, A., 1995. Nature of the Moho Transition zone in the Oman ophiolite. J. Petrol. 36, 777-796. https://doi.org/10.1093/petrology/36.3.777

11. Boudier, F., Nicolas, A., 1977. Structural control on the partial melting of the Lanzo peridotite, in: AGU Chapman Conf. Proc. Bull. 96. Geol. Min. Industries, Oregon Dep.

12. Boudier, F., Nicolas, A., Ildefonse, B., Jousselin, D., 1997. EPR microplates, a model for the Oman Ophiolite. Terra Nov. 9, 79-82. https://doi.org/10.1111/j.1365-3121.1997.tb00007.x

13. Braun, M.G., Kelemen, P.B., 2002. Dunite distribution in the Oman Ophiolite: Implications for melt flux through porous dunite conduits. Geochemistry, Geophys. Geosystems 3, 1-21.

684

14. Brenan, J.M., Bennett, N.R., Zajacz, Z., 2016. Experimental results on fractionation of the highly 685 siderophile elements (HSE) at variable pressures and temperatures during planetary and magmatic

15. Büchl, A., Brügmann, G.E., Batanova, V.G., Hofmann, A.W., 2004. Os mobilization during melt percolation: The evolution of Os isotope heterogeneities in the mantle sequence of the Troodos ophiolite, Cyprus. Geochim. Cosmochim. Acta 68, 3397-3408. https://doi.org/10.1016/j.gca.2004.02.005

16. Büchl, A., Brügmann, G.E., Batanova, V.G., Münker, C., Hofmann, A.W., 2002. Melt percolation monitored by Os isotopes and HSE abundances: A case study from the mantle section of the Troodos Ophiolite. Earth Planet. Sci. Lett. 204, 385-402. https://doi.org/10.1016/S0012- 
17. Daines, M.J., Kohlstedt, D.L., 1994. The transition from porous to channelized flow due to melt/rock reaction during melt migration. Geophys. Res. Lett. 21, 145-148. https://doi.org/10.1029/93GL03052

18. Elkins, L.J., Bourdon, B., Lambart, S., 2019. Testing pyroxenite versus peridotite sources for marine basalts using U-series isotopes. Lithos 332-333, 226-244. https://doi.org/10.1016/j.lithos.2019.02.011

19. Ernewein, M., Pflumio, C., Whitechurch, H., 1988. The death of an accretion zone as evidenced by the magmatic history of the Sumail ophiolite (Oman). Tectonophysics 151, 247-274.

20. Fonseca, R.O.C., Laurenz, V., Mallmann, G., Luguet, A., Hoehne, N., Jochum, K.P., 2012. New constraints on the genesis and long-term stability of Os-rich alloys in the Earth's mantle. Geochim.

22. Godard, M., Bosch, D., Einaudi, F., 2006. A MORB source for low-Ti magmatism in the Semail

21. Gannoun, A., Burton, K.W., Day, J.M.D., Harvey, J., Schiano, P., Parkinson, I., 2016. Highly siderophile element and Os isotope systematics of volcanic rocks at divergent and convergent plate boundaries and in intraplate settings. Rev. Mineral. Geochemistry 81, 651-724. https://doi.org/10.2138/rmg.2016.81.11

ophiolite. Chem. Geol. 234, 58-78. https://doi.org/10.1016/j.chemgeo.2006.04.005

23. Godard, M., Jousselin, D., Bodinier, J.L., 2000. Relationships between geochemistry and structure beneath a palaeo-spreading centre: A study of the mantle section in the Oman ophiolite. Earth Planet. Sci. Lett. 180, 133-148. https://doi.org/10.1016/S0012-821X(00)00149-7

24. Guilmette, C., Smit, M.A., van Hinsbergen, D.J.J., Gürer, D., Corfu, F., Charette, B., Maffione, M., Rabeau, O., Savard, D., 2018. Forced subduction initiation recorded in the sole and crust of the Semail ophiolite of Oman. Nat. Geosci. 11, 688-695. https://doi.org/10.1038/s41561-018-0209-2 mantle peridotites from the Wadi Tayin massif, Oman ophiolite; Major and trace element geochemistry, and Os isotope and PGE systematics. J. Petrol. 51, 201-227. 
https://doi.org/10.1093/petrology/egp077

722

723

26. Hebert, L.B., Montési, L.G.J., 2010. Generation of permeability barriers during melt extraction at mid-ocean ridges. Geochem. Geophys. Geosyst. 11, Q12008. https://doi.org/10.1029/2010GC003270

27. Jébrak, M., 1997. Hydrothermal breccias in vein-type ore deposits: A review of mechanisms, morphology and size distribution. Ore Geol. Rev. 12, 111-134.

28. Jousselin, D., Nicolas, A., Boudier, F., 1998. Detailed mapping of a mantle diapir below a paleospreading center in the Oman ophiolite. J. Geophys. Res. Solid Earth 103, 18153-18170. https://doi.org/10.1029/98JB01493

29. Kelemen, P.B., 1990. Reaction between ultramafic rock and fractionating basaltic magma I. Phase relations, the origin of calc-alkaline magma series, and the formation of discordant dunite. J. Petrol. 31, 51-98. https://doi.org/10.1093/petrology/31.1.51

30. Kelemen, P.B., Shimizu, N., Salters, V.J.M., 1995. Extraction of mid-ocean-ridge basalt from the upwelling mantle by focused flow of melt in dunite channels. Nature $375,747-753$. https://doi.org/10.1038/375747a0

31. Koga, K.T., Kelemen, P.B., Shimizu, N., 2001. Petrogenesis of the crust-mantle transition zone and the origin of lower crustal wehrlite in the Oman ophiolite. Geochemistry, Geophys. Geosystems 2. https://doi.org/10.1029/2000GC000132

32. Kogiso, T., Hirschmann, M.M., Reiners, P.W., 2004. Length scales of mantle heterogeneities and their relationship to ocean island basalt geochemistry. Geochim. Cosmochim. Acta 68, 345-360. https://doi.org/10.1016/\$0016-7037(03)00419-8

33. Lambart, S., Laporte, D., Schiano, P., 2009. An experimental study of focused magma transport and basalt-peridotite interactions beneath mid-ocean ridges: Implications for the generation of primitive MORB compositions. Contrib. to Mineral. Petrol. 157, 429-451. https://doi.org/10.1007/s00410-008-0344-7

34. Levasseur, S., Birck, J.L., Allègre, C.J., 1998. Direct measurement of femtomoles of osmium and the 1870 s/1860s ratio in seawater. Science $282,272-274$. 
35. Lippard, S.J., Shelton, A.W., Gass, I.G., 1986. The Ophiolite of Northern Oman, in: The Geological Society Memoirs. Backwell Scientific Publications, London, p. 178. https://doi.org/10.1144/GSL.MEM.1986.011.01.03

36. Lorand, J.P., Alard, O., Godard, M., 2009. Platinum-group element signature of the primitive mantle rejuvenated by melt-rock reactions: evidence from Sumail peridotites (Oman Ophiolite). Terra Nov. 21, 35-40. https://doi.org/10.1111/j.1365-3121.2008.00850.x

37. Lorand, J.P., Luguet, A., 2016. Chalcophile and siderophile elements in mantle rocks: trace elements controlled by trace minerals. Rev. Mineral. Geochemistry 81, 441-488. https://doi.org/10.2138/rmg.2016.81.08

38. MacLeod, C.J., Lissenberg, C.J., Bibby, L.E., 2013. "Moist MORB" axial magmatism in the Oman ophiolite: The evidence against a mid-ocean ridge origin. Geology 41, 459-462. https://doi.org/10.1130/G33904.1

39. McCulloch, M.T., Gregory, R.T., Wasserburg, G.J., Taylor, H.P.J., 1981. Sm-Nd, Rb-Sr, and 180/160 isotopic systematics in an oceanic crustal section: Evidence from the Samail Ophiolite. J. Geophys. Res. Solid Earth 86, 2721-2735. https://doi.org/10.1029/JB086iB04p02721

40. Meisel, T., Walker, R.J., Irving, A.J., Lorand, J.P., 2001. Osmium isotopic compositions of mantle xenoliths : A global perspective. Geochim Cosmochim Acta 65, 1311-1323.

41. Morgan, Z., Liang, Y., 2003. An experimental and numerical study of the kinetics of harzburgite reactive dissolution with applications to dunite dike formation. Earth Planet. Sci. Lett. 214, 59-74. https://doi.org/10.1016/\$0012-821X(03)00375-3

42. Mungall, J.E., Brenan, J.M., 2014. Partitioning of platinum-group elements and Au between sulfide liquid and basalt and the origins of mantle-crust fractionation of the chalcophile elements. Geochim. Cosmochim. Acta 125, 265-289. https://doi.org/10.1016/j.gca.2013.10.002

43. Nicolas, A., 1986. A Melt Extraction Model Based on Structural Studies in Mantle Peridotites. J. Petrol. 27, 999-1022. https://doi.org/10.1093/petrology/27.4.999

44. Nicolas, A., Boudier, F., 2001. Oman \& UAE ophiolite. Mar. Geophys. Res. 21. 
45. Nicolas, A., Boudier, F., Ildefonse, B., Ball, E., 2000a. Accretion of Oman and United Arab Emirates ophiolite - Discussion of a new structural map. Mar. Geophys. Res. 21, 147-180. https://doi.org/10.1023/A:1026769727917

46. Nicolas, A., Ildefonse, B., Boudier, F., Lenoir, X., Ben Ismail, W., 2000b. Dike distribution in the Oman-United Arab Emirates ophiolite. Mar. Geophys. Res. 21, 269-287. https://doi.org/10.1023/A:1026718026951

47. Nicolas, A., Prinzhofer, A., 1983. Cumulative or Residual Origin for the Transition Zone in Ophiolites: Structural Evidence. J. Petrol. 24, 188-206. https://doi.org/10.1093/petrology/24.2.188 48. O’Driscoll, B., Day, J.M.D., Walker, R.J., Daly, J.S., McDonough, W.F., Piccoli, P.M., 2012. Chemical heterogeneity in the upper mantle recorded by peridotites and chromitites from the Shetland Ophiolite Complex, Scotland. Earth Planet. Sci. Lett. 333-334, 226-237. https://doi.org/10.1016/j.epsl.2012.03.035

49. O’Driscoll, B., González-Jiménez, J.M., 2016. Petrogenesis of the Platinum-Group Minerals. Rev. Mineral. Geochemistry 81, 489-578. https://doi.org/10.2138/rmg.2016.81.09

50. O'Hara, M.J., 1965. Primary magmas and the origin of basalts. Scottish J. Geol. 1, 19-40. https://doi.org/10.1144/sjg01010019

51. Peucker-Ehrenbrink, B., Hanghøj, K., Atwood, T., Kelemen, P.B., 2012. Rhenium-osmium isotope systematics and platinum group element concentrations in oceanic crust. Geology 40, 199-202. https://doi.org/10.1130/G32431.1

52. Ravizza, G., Blusztajn, J., Prichard, H.M., 2001. Re-Os systematics and platinum-group element distribution in metalliferous sediments from the Troodos ophiolite. Earth Planet. Sci. Lett. 188, 369-381. https://doi.org/10.1016/S0012-821X(01)00337-5

53. Richardson, C.N., 1998. Melt flow in a variable viscosity matrix. Geophys. Res. Lett. 25, 1099-1102. https://doi.org/10.1029/98GL50565

54. Rioux, M., Bowring, S., Kelemen, P.B., Gordon, S., Dudás, F., Miller, R., 2012. Rapid crustal accretion and magma assimilation in the Oman-U.A.E. ophiolite: High precision U-Pb zircon geochronology of the gabbroic crust. J. Geophys. Res. Solid Earth 117, 1-12. 
55. Rospabé, M., Benoit, M., Ceuleneer, G., Hodel, F., Kaczmarek, M.A., 2018. Extreme geochemical variability through the dunitic transition zone of the Oman ophiolite : Implications for melt/fluidrock reactions at Moho level beneath oceanic spreading centers. Geochim Cosmochim Acta 234, 1-23. https://doi.org/10.1016/j.gca.2018.05.012

56. Rubin, A.M., 1995. Propagation of Magma-Filled Cracks. Annu. Rev. Earth Planet. Sci. 23, 287-336. https://doi.org/10.1146/annurev.ea.23.050195.001443

57. Senda, R., Suzuki, K., Morishita, T., Takazawa, E., The Oman Drilling Project Science Party, 2020. The PGE and Os isotope variations in the mantle transition zone from the Samail Ophiolite from Muscat, Sultanate of Oman, p. 1.

58. Sergeev, D.S., Dijkstra, A.H., Meisel, T., Brügmann, G.E., Sergeev, S.A., 2014. Traces of ancient mafic layers in the Tethys oceanic mantle. Earth Planet. Sci. Lett. 389, 155-166.

61. Stevenson, D.J., 1989. Spontaneous small-scale melt segregation in partial melts undergoing https://doi.org/10.1016/j.epsl.2013.10.039

59. Smoliar, M.I., Walker, R.J., Morgan, J.W., 1996. Re-Os Ages of Group IIA, IIIA, IVA, and IVB Iron Meteorites. Science 271, 1099 LP - 1102. https://doi.org/10.1126/science.271.5252.1099

60. Sparks, D.W., Parmentier, E.M., 1991. Melt extraction from the mantle beneath spreading centers. deformation. Geophys. Res. Lett. 16, 1067-1070. https://doi.org/10.1029/GL016i009p01067

62. Stolper, E., 1980. A phase diagram for mid-ocean ridge basalts: Preliminary results and implications for petrogenesis. Contrib. to Mineral. Petrol. 74, 13-27. https://doi.org/10.1007/BF00375485 63. Vernières, J., Godard, M., Bodinier, J.L., 1997. A plate model for the simulation of trace element fractionation during partial melting and magma transport in the Earth's upper mantle. J. Geophys. Res. B Solid Earth 102, 24771-24784. https://doi.org/10.1029/97jb01946

64. Xiong, Q., Xu, Y., González-Jiménez, J.M., Liu, J., Alard, O., Zheng, J.P., Griffin, W.L., O’Reilly, S.Y., 
829 2020a. Sulfide in dunite channels reflects long-distance reactive migration of mid-ocean-ridge

830 melts from mantle source to crust: A Re-Os isotopic perspective. Earth Planet. Sci. Lett. 531, 1-10.

831 https://doi.org/10.1016/j.epsl.2019.115969

832 65. Xiong, Q., Xu, Y., González-Jiménez, J.M., Liu, J., Alard, O., Zheng, J.P., Griffin, W.L., O’Reilly, S.Y., 8332020 b. Corrigendum to "Sulfide in dunite channels reflects long-distance reactive migration of 834 mid-ocean-ridge melts from mantle source to crust: A Re-Os isotopic perspective." Earth Planet.

835 Sci. Lett. 535, 1. https://doi.org/10.1016/j.epsl.2020.116136 